University of South Florida

DIGITAL COMMONS Digital Commons @ University of @ UNIVERSITY OF SOUTH FLORIDA South Florida

6-1-2013

\title{
Forecasting Paratransit Services Demand - Review and Recommendations
}

CUTR

Follow this and additional works at: https://digitalcommons.usf.edu/cutr_nctr

\section{Recommended Citation}

"Forecasting Paratransit Services Demand - Review and Recommendations," National Center for Transit Research (NCTR) Report No. CUTR-NCTR-RR-2011-06, Center for Urban Transportation Research, University of South Florida, 2013.

DOI: https://doi.org/10.5038/CUTR-NCTR-RR-2011-06

Available at: https://scholarcommons.usf.edu/cutr_nctr/105

This Technical Report is brought to you for free and open access by the National Center for Transit Research (NCTR) Archive (2000-2020) at Digital Commons @ University of South Florida. It has been accepted for inclusion in Research Reports by an authorized administrator of Digital Commons @ University of South Florida. For more information, please contact digitalcommons@usf.edu. 

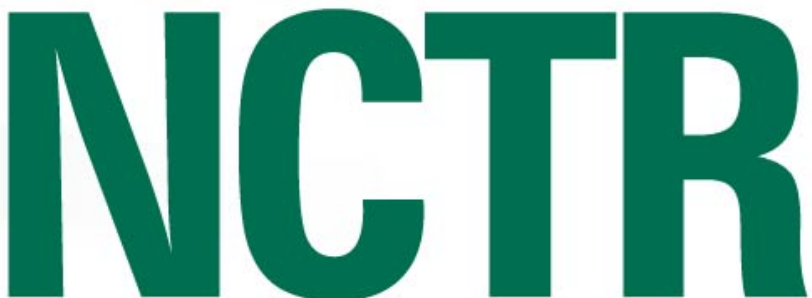

NATIONAL CENTER for TRANSIT RESEARCH

\section{Forecasting Paratransit Services Demand - Review and Recommendations}

FINAL REPORT

PROJECT NO. BDK85 977-34

PREPARED FOR

Florida Department of Transportation and the Florida Commission for the Transportation Disadvantaged
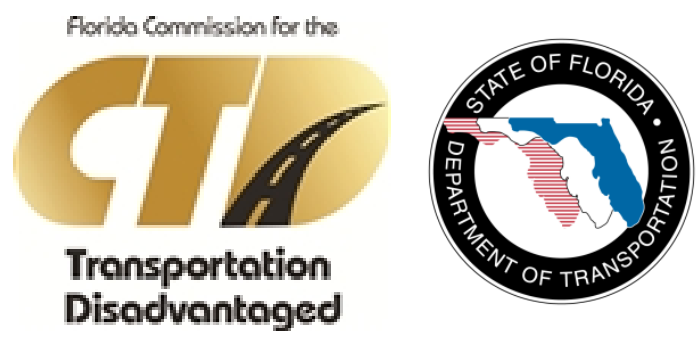


\section{DISCLAIMER}

The contents of this report reflect the views of the authors, who are responsible for the facts and the accuracy of the information presented herein. This document is disseminated under the sponsorship of the Department of Transportation University Transportation Centers Program and the Florida Department of Transportation, in the interest of information exchange. The U.S. Department of Transportation, the Florida Department of Transportation, and the Florida Commission for the Transportation Disadvantaged assume no liability for the contents or use thereof.

The opinions, findings, and conclusions expressed in this publication are those of the authors and not necessarily those of the Florida Department of Transportation or the Florida Commission for the Transportation Disadvantaged. 


\title{
Forecasting Paratransit Services \\ Demand - Review and Recommendations
}

\author{
Final Report \\ Prepared for: \\ Florida Department of Transportation and the \\ Florida Commission for the Transportation Disadvantaged

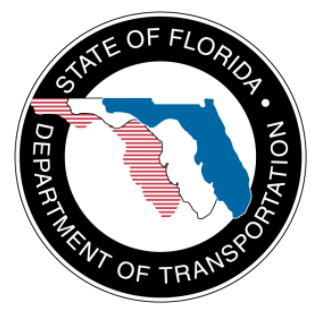 \\ Project Manager: \\ Karen Somerset
}

Florida Commission for the Transportation Disadvantaged

Prepared by:

Jay A. Goodwill and Ann Joslin

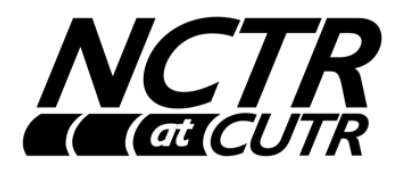

National Center for Transit Research

Center for Urban Transportation Research (CUTR)

University of South Florida

4202 East Fowler Avenue, CUT100

Tampa, Florida 33620-5375

June 2013

Project No. BDK85 977-34 


\section{Metric Conversion}

\begin{tabular}{|c|c|c|c|c|}
\hline SYMBOL & $\begin{array}{l}\text { WHEN YOU } \\
\text { KNOW }\end{array}$ & MULTIPLY BY & TO FIND & SYMBOL \\
\hline \multicolumn{5}{|c|}{ LENGTH } \\
\hline in & inches & 25.4 & millimeters & $\mathrm{mm}$ \\
\hline ft & feet & 0.305 & meters & $\mathrm{m}$ \\
\hline yd & yards & 0.914 & meters & $\mathrm{m}$ \\
\hline $\mathbf{m i}$ & miles & 1.61 & kilometers & $\mathrm{km}$ \\
\hline \multicolumn{5}{|c|}{ VOLUME } \\
\hline floz & fluid ounces & 29.57 & milliliters & $\mathrm{mL}$ \\
\hline gal & gallons & 3.785 & liters & L \\
\hline $\mathrm{ft}^{3}$ & cubic feet & 0.028 & cubic meters & $\mathrm{m}^{3}$ \\
\hline$y d^{3}$ & cubic yards & 0.765 & cubic meters & $\mathrm{m}^{3}$ \\
\hline \multicolumn{5}{|c|}{ NOTE: volumes greater than $1000 \mathrm{~L}$ shall be shown in $\mathrm{m}^{3}$} \\
\hline \multicolumn{5}{|c|}{ MASS } \\
\hline $\mathbf{o z}$ & ounces & 28.35 & grams & g \\
\hline lb & pounds & 0.454 & kilograms & $\mathrm{kg}$ \\
\hline $\mathbf{T}$ & short tons $(2000 \mathrm{lb})$ & 0.907 & $\begin{array}{l}\text { megagrams } \\
\text { (or "metric } \\
\text { ton") }\end{array}$ & $\mathrm{Mg}$ (or "t") \\
\hline \multicolumn{5}{|c|}{ TEMPERATURE (exact degrees) } \\
\hline${ }^{\circ} \mathbf{F}$ & Fahrenheit & $\begin{array}{c}5(F-32) / 9 \\
\operatorname{or}(F-32) / 1.8\end{array}$ & Celsius & ${ }^{\circ} \mathrm{C}$ \\
\hline
\end{tabular}




\begin{tabular}{|c|c|c|c|c|}
\hline $\begin{array}{l}\text { 1. Report No. } \\
\text { BDK85 977-34 }\end{array}$ & \multicolumn{2}{|c|}{ 2. Government Accession No. } & \multicolumn{2}{|l|}{ 3. Recipient's Catalog No. } \\
\hline \multirow{2}{*}{\multicolumn{3}{|c|}{$\begin{array}{l}\text { 4. Title and Subtitle } \\
\text { Forecasting Paratransit Services Demand - Review and } \\
\text { Recommendations }\end{array}$}} & \multicolumn{2}{|l|}{$\begin{array}{l}\text { 5. Report Date } \\
\text { June } 2013\end{array}$} \\
\hline & & & \multicolumn{2}{|c|}{ 6. Performing Organization Code } \\
\hline \multicolumn{3}{|c|}{$\begin{array}{l}\text { 7. Author(s) } \\
\text { Jay A. Goodwill and Ann Joslin }\end{array}$} & \multicolumn{2}{|c|}{$\begin{array}{l}\text { 8. Performing Organization Report No. } \\
\text { NCTR 77938/BDK85 977-34 } \\
\text { U.S. DOT DTRS98-G-0032 }\end{array}$} \\
\hline \multirow{2}{*}{\multicolumn{3}{|c|}{$\begin{array}{l}\text { 9. Performing Organization Name and Address } \\
\text { National Center for Transit Research } \\
\text { Center for Urban Transportation Research (CUTR) } \\
\text { University of South Florida } \\
4202 \text { East Fowler Avenue, CUT100, Tampa, FL 33620-5375 }\end{array}$}} & \multicolumn{2}{|l|}{ 10. Work Unit No. (TRAIS) } \\
\hline & & & \multicolumn{2}{|l|}{$\begin{array}{l}\text { 11. Contract or Grant No. } \\
\text { BDK85 977-34 }\end{array}$} \\
\hline \multirow{2}{*}{\multicolumn{3}{|c|}{$\begin{array}{l}\text { 12. Sponsoring Agency Name and Address } \\
\text { Florida Department of Transportation } \\
\text { Research Center } \\
605 \text { Suwannee Street, MS30 } \\
\text { Tallahassee, Florida } 32399 \\
\text { Research and Innovative Technology Administration } \\
\text { U.S. Department of Transportation } \\
\text { Mail Code RDT-30, } 1200 \text { New Jersey Ave, SE, Room E33 } \\
\text { Washington, D.C. } 20590-0001\end{array}$}} & \multicolumn{2}{|c|}{$\begin{array}{l}\text { 13. Type of Report and Period Covered } \\
\text { Final Report 05/20/11-06/30/13 }\end{array}$} \\
\hline & & & \multicolumn{2}{|c|}{ 14. Sponsoring Agency Code } \\
\hline \multicolumn{5}{|l|}{ 15. Supplementary Notes } \\
\hline \multirow{3}{*}{\multicolumn{5}{|c|}{$\begin{array}{l}\text { 16. Abstract } \\
\text { Travel demand forecasting tools for Florida's paratransit services are outdated, utilizing old national trip } \\
\text { generation rate generalities and simple linear regression models. In its guidance for the development of } \\
\text { mandated Transportation Disadvantaged Service Plans (TDSP), the Florida Commission for the Transportation } \\
\text { Disadvantaged (CTD) refers transit planners to the May } 1993 \text { "Methodology Guidelines for Forecasting TD } \\
\text { Transportation Demand at the County Level" to develop forecasts of transportation disadvantaged } \\
\text { populations. } \\
\quad \text { This report examines the current demand forecasting procedure, examines samples of other forecasting } \\
\text { methods, and details critical factors that should be considered in addressing the development of a new } \\
\text { paratransit demand forecasting model. }\end{array}$}} \\
\hline & & & & \\
\hline & & & & \\
\hline \multicolumn{2}{|c|}{$\begin{array}{l}\text { 17. Key Word } \\
\text { Paratransit, demand estimation, ADA, transportation } \\
\text { disadvantaged }\end{array}$} & \multicolumn{3}{|c|}{$\begin{array}{l}\text { 18. Distribution Statement } \\
\text { No Restrictions }\end{array}$} \\
\hline $\begin{array}{l}\text { 19. Security Classif. (of this report) } \\
\text { Unclassified }\end{array}$ & $\begin{array}{r}\text { 20. Security Classif } \\
\text { Unclass }\end{array}$ & $\begin{array}{l}\text { of this page) } \\
\text { ied }\end{array}$ & $\begin{array}{c}\text { 21. No. of Pages } \\
55\end{array}$ & 22. Price \\
\hline
\end{tabular}


This page left blank 


\section{Executive Summary}

The provision of mobility options, including paratransit services, is a critical component in addressing the needs of all Florida residents and specifically the transportation disadvantaged population. The transportation disadvantaged (TD) are defined as "those persons who because of physical or mental disability, income status, or age are unable to transport themselves or purchase transportation and are, therefore, dependent on others to obtain access to health care, employment, education, shopping, social activities, or other life-sustaining activities or children who are handicapped or high-risk or at-risk as defined in s. 411.202, Florida Statutes." (Chapter 427, Florida Statutes)

The Florida Commission for the Transportation Disadvantaged (CTD) is an independent state agency serving as the policy development and implementation agency for Florida's Transportation Disadvantaged Program. The CTD has oversight responsibility for the Community Transportation Coordinators (CTCs), single entities that coordinate TD services for each of Florida's 67 counties. The CTC shares the responsibility for the preparation of a Transportation Disadvantaged Service Plan (TDSP) with the local planning agency. A required component of the TDSP is a forecast of the TD population.

With the growing population of seniors and persons with disabilities seeking more mobility opportunities, there needs to be an up-to-date toolkit for transportation agencies to forecast demand for these customer markets. This information is critical for transit planners and operators to interpret service demand so that operating and capital program needs and priorities can be identified.

This research assesses the current Florida and national methodologies and techniques utilized for paratransit service demand and provides a new analytical tool for forecasting the demand for TD services. The research findings are not only applicable for the Florida CTD transportation disadvantaged services but can also be useful in analyzing fixed route complementary ADA paratransit services, and other specialized service markets.

The paratransit demand methodology currently utilized by many CTCs, planning agencies, and public transportation operators for the preparation of TDSPs and other demand estimation applications within the state of Florida was developed in 1993. The methodology was based on trip rates that were derived from a 1988 Urban Mass Transportation Administration (the predecessor of today's Federal Transit Administration) study that utilized trip rates derived from travel behavior in the San Francisco area.

While the methodology was appropriate at the time, the CTD has matured, and with the passage of the Americans with Disabilities Act (ADA) in 1990, significant changes have occurred in terms of the mobility options that are available for persons with disabilities. For example, as a result of the passage of ADA, many of the TD trips can now be accommodated by the community's fixed-route transit services. Based on these changes, the definitions and categories used in the existing methodology may no longer be appropriate or relevant for the examination of the TD population or their travel needs. 
Additionally, the existing methodology was based on 1990 U.S. Census data. This outdated data source could not account for changes in the population that have occurred in the 20 years since the methodology's development. Much of the demographic and socio-economic data that is necessary for the preparation of TD population and demand forecasts are now collected by the U.S. Census Bureau on an annual basis. This richer data source captures changing population characteristics that influence transportation demand.

As a result of this research effort, a dynamic spreadsheet that can be frequently updated with new data was developed to assist Florida transportation planners with TD demand forecasting. Unlike the existing forecasting tool, this approach does require some user input, and the inputs are straightforward and can be completed by most anyone with basic spreadsheet skills. This new analytical tool does not require complex data sets or specialized software often required of more sophisticated model resources that may not be available to all agencies.

Step-by-step instructions are provided for accessing the required inputs, including the U.S. Census Bureau's American Community Survey (ACS) age, income, disability, and county level population data. Other data used in the model, such as those from the National Household Travel Survey (NHTS) and the U.S. Census Bureau's Survey of Income and Program Participation (SIPP), have been pre-coded in the spreadsheet tool for ease of use.

The TD methodology described in this report can serve as a resource which is easily updated with current data, enables users to better analyze various sub-components of the TD market, and can be complemented with local knowledge and information for further customization. 


\section{Table of Contents}

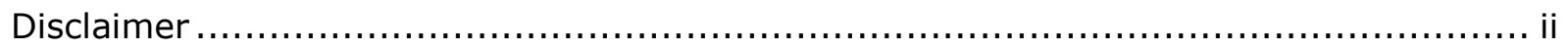

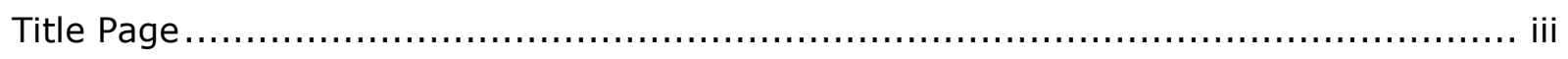

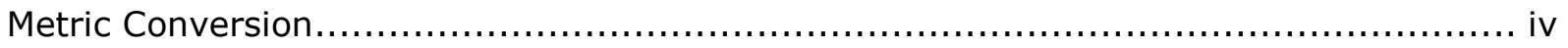

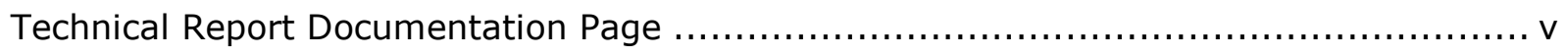

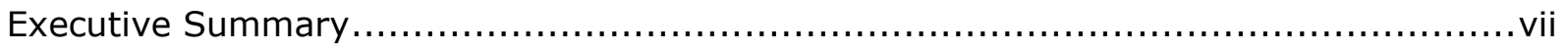

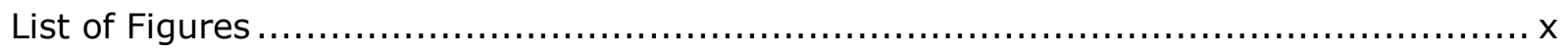

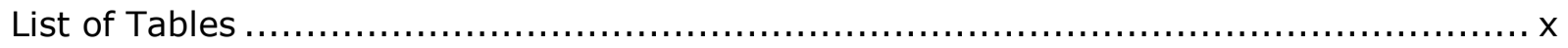

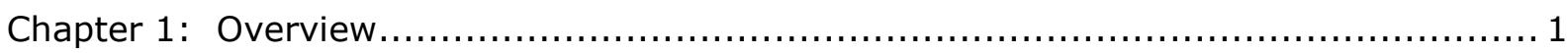

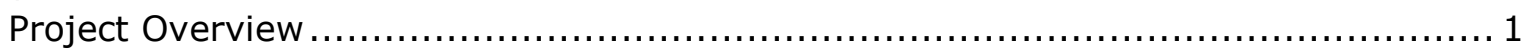

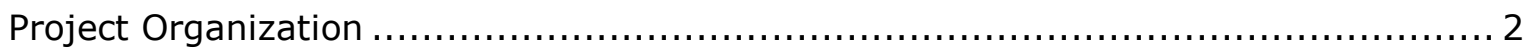

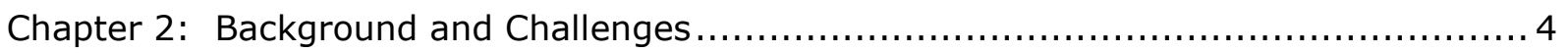

Florida Commission for the Transportation Disadvantaged $\ldots \ldots \ldots \ldots \ldots \ldots \ldots \ldots \ldots \ldots \ldots . \ldots$

Methodology Guidelines for Forecasting TD Transportation Demand

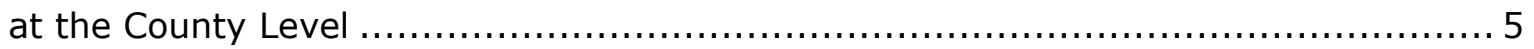

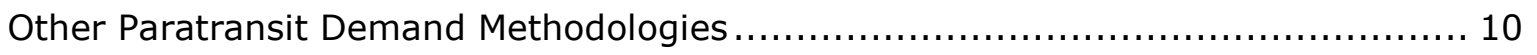

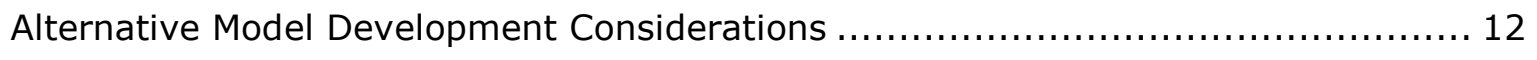

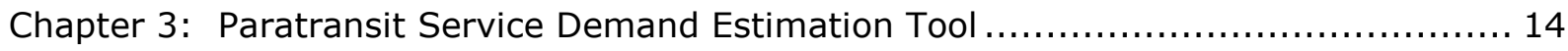

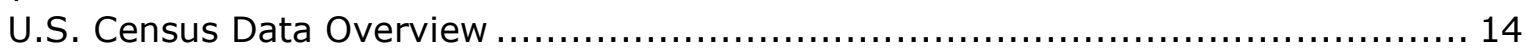

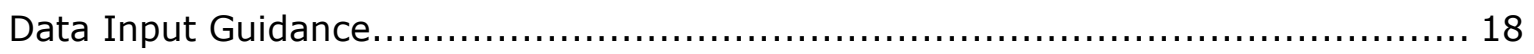

Paratransit Demand Estimation Spreadsheets ................................... 29

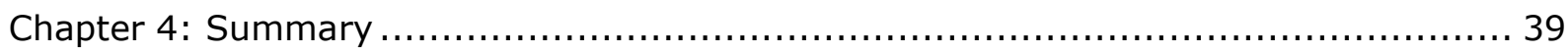

Appendix A

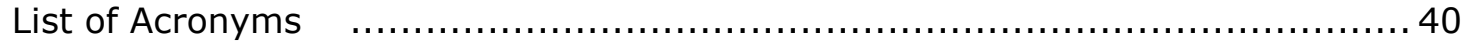

Appendix B

University of Florida, Bureau of Economic and Business Research, Florida Population Studies, Bulletin 162 (Revised), March $2012 \ldots \ldots \ldots \ldots \ldots \ldots . \ldots 42$

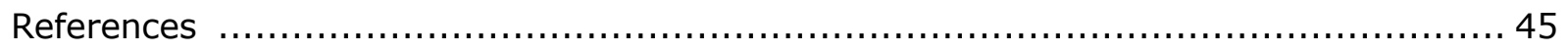




\section{List of Figures}

Figure 2-1: Florida Coordinated Transportation System Organization ................... 5 Figure 2-2: Category I Transportation Disadvantaged Population Groups ................. 9

Figure 3-1: American Community Survey Questions Designed to Measure Disability ..... 17

Figure 3-2: General Transportation Disadvantaged Population Groups ..................... 30

Figure 3-2: General Transportation Disadvantaged Population Groups ..................... 33

\section{List of Tables}

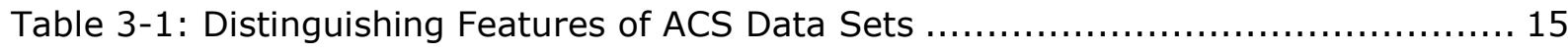

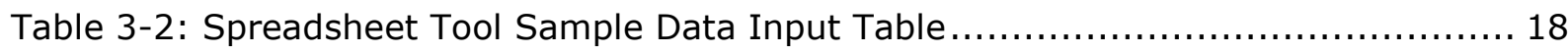

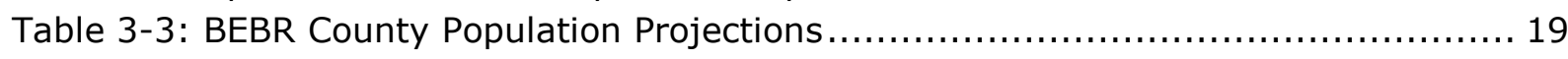

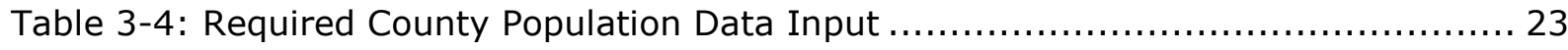

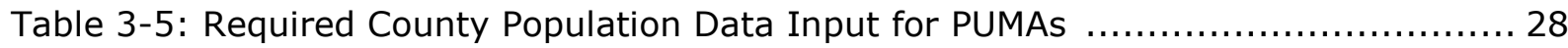

Table 3-6: Calculation of General Transportation Disadvantaged Population................ 31

Table 3-7: Calculation of Critical Need Transportation Disadvantaged

Population with Severe Disabilities ....................................... 34

Table 3-8: Calculation of Critical Need Transportation Disadvantaged

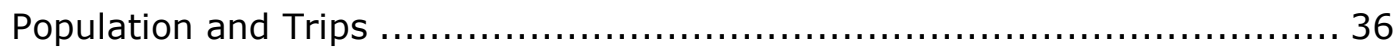

Table 3-9: Forecast of General and Critical Need Transportation Disadvantaged

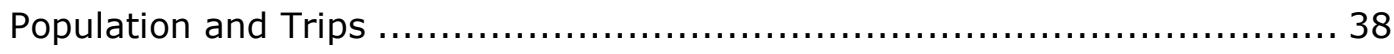




\section{Chapter 1 Overview}

\section{Project Overview}

Travel demand forecasting tools for Florida's paratransit services are outdated, utilizing old national trip generation rates and simple linear regression models. Additionally, the current methodologies do not address several relevant contributory factors that impact service demand.

The Florida Commission for the Transportation Disadvantaged (CTD) is an independent state agency serving as the policy development and implementation agency for Florida's Transportation Disadvantaged Program. The transportation disadvantaged (TD) are defined as "those persons who because of physical or mental disability, income status, or age are unable to transport themselves or purchase transportation and are, therefore, dependent on others to obtain access to health care, employment, education, shopping, social activities, or other life-sustaining activities or children who are handicapped or high-risk or at-risk as defined in s. 411.202, Florida Statutes." (Chapter 427, Florida Statutes)

In its guidance for the development of mandated Transportation Disadvantaged Service Plans (TDSPs), the CTD refers transit planners to the May 1993 "Methodology Guidelines for Forecasting TD Transportation Demand at the County Level" to develop forecasts of transportation disadvantaged populations.

This demand estimate methodology is approximately 20 years old and it predates some significant developments in the Florida public transportation environment, including:

- The passage of the Americans with Disabilities Act of 1990 (ADA), which resulted in the public transportation industry's mandate to accommodate the needs of persons with disabilities through the purchase of accessible buses and the development of complementary ADA paratransit services for those passengers unable to access fixed route transit services.

Following the passage of $A D A$ and the subsequent mandated requirements established by the Federal Transit Administration (FTA), complementary ADA paratransit services have developed which improve access to public transportation. These services were not addressed or accounted for in the 1993 methodology.

- The demographics of the nation and Florida have changed dramatically in the past two decades. In the Administration on Aging's A Profile of Older Americans: 2011, ${ }^{1}$ the population of the United States age 65 years and older, numbered 40.4 million in 2010. The population 65 and over is projected to increase to 55 million in 2020 (a $36 \%$ increase). By 2030, there will be about 72.1 million older persons, over twice the number in 2000. 
In Florida, persons 65 years and over represented $17.4 \%$ of the state's 2010 population. By 2030 this segment is expected to represent over a third of the state's population (33.4 percent). These demographic trends will have a significant impact on Florida's transportation networks - specifically paratransit services. This impact was not factored into the methodology developed in 1993.

- The National Center for Senior Transportation (NCST) estimates that 600,000 U.S. residents age 70 and older stop driving each year. The average gap between death and the end of driving privileges currently stands at approximately 6 years for men and 10 years for women. Non-driving seniors tend to make fewer trips, approximately 15 percent fewer for medical appointments, and 65 percent fewer trips for social, family, religious and other life-enhancing purposes. NCST estimates that more than 50 percent of non-driving seniors stay at home on any given day due to a lack of mobility options.

The provision of mobility options, including paratransit services, is a critical component in addressing the needs of all Florida residents and specifically the TD population. With the growing population of seniors and persons with disabilities seeking more mobility opportunities, there needs to be an up-to-date toolkit for transportation agencies to forecast demand for TD customer markets. This information is critical for transit planners and operators to interpret service demands and translate those into operating and capital program needs that will provide the basis for program priorities.

This research assesses the current Florida and national methodologies and techniques utilized for paratransit service demand and identifies a new analytical tool for forecasting the demand for TD services. The research findings are not only applicable to Florida's transportation disadvantaged services, but can also be useful in analyzing fixed route complementary ADA paratransit services, and other specialized service markets.

\section{Report Organization}

\section{Chapter Two - Background and Challenges}

This chapter provides the background on the need for the development of new paratransit demand forecasts. An overview of the CTD program for the delivery of TD trips in Florida is provided. An examination of the current demand estimation approach used in the forecast of the TD population in Florida and its shortcomings are presented.

Following an examination of other demand estimation approaches used over the past few decades, the chapter concludes with a summary of several considerations used in the development of the new methodology. 


\section{Chapter Three - Paratransit Service Demand Estimation Tool}

To serve as an aid in the development of TD population and travel demand estimates, a spreadsheet tool was developed. It was designed in a way that enables users to input the most current U.S. Census Bureau demographic and socio-economic data available. Once the user input is complete a series of automated formulas are used to project future travel demand.

This chapter describes the U.S. Census Bureau's American Community Survey (ACS) data used to calculate the TD population. Step-by-step instructions are included to allow a user to easily access the ACS data and complete the input spreadsheet fields. Examples of the completed demand estimate spreadsheets are presented along with an explanation of other demand methodology assumptions and data sources used in the methodology.

\section{Chapter Four - Summary}

The final chapter provides a brief recap of the research project, its process and end product. 


\section{Chapter 2 \\ Background and Challenges}

With the growing population of seniors and persons with disabilities seeking more mobility opportunities, it is critical for transportation planners and mobility service providers to have the ability to adequately interpret customer market demand for the purpose of projecting operating and capital needs that will provide the basis for program priorities.

Within Florida, there is a requirement for the development of demand estimates of the TD population, yet the existing recommended methodology is outdated and new tools and approaches are needed in order to effectively plan for the future.

\section{Florida Commission for the Transportation Disadvantaged}

The CTD is an independent state agency serving as the policy development and implementation agency for Florida's Transportation Disadvantaged Program. The Commission is administratively housed within the Florida Department of Transportation. The CTD mission is: "To ensure the availability of efficient, cost-effective and quality transportation services for transportation disadvantaged persons."

The Florida CTD is charged with serving the mobility needs of the TD population that includes "those persons who because of physical or mental disability, income status, or age are unable to transport themselves or purchase transportation and are, therefore, dependent on others to obtain access to health care, employment, education, shopping, social activities, or other life-sustaining activities or children who are handicapped or highrisk or at-risk as defined in s. 411.202, Florida Statutes." (Chapter 427, Florida Statutes)

Florida's TD program was created in 1979 and reenacted in 1989. The 1989 act created the Florida Transportation Disadvantaged Commission (currently the Florida Commission for the Transportation Disadvantaged) and enhanced local participation in the planning and delivery of coordinated transportation services through the creation of local coordinating boards (LCBs) and Community Transportation Coordinators (CTCs). Local planning organizations perform long-range planning, and assist the Commission and LCBs in implementing the TD program in designated service areas. Figure 2-1 provides a graphic representation of the Florida CTD coordination system.

The CTCs are businesses or local public transportation providers that are responsible for providing or arranging the delivery of transportation services to the TD population. The designated CTC may provide all trips as a sole source, or the CTC may provide some trips and subcontract some (partial brokerage). The CTC may also function as a complete brokerage subcontracting all trips to approved operators. 


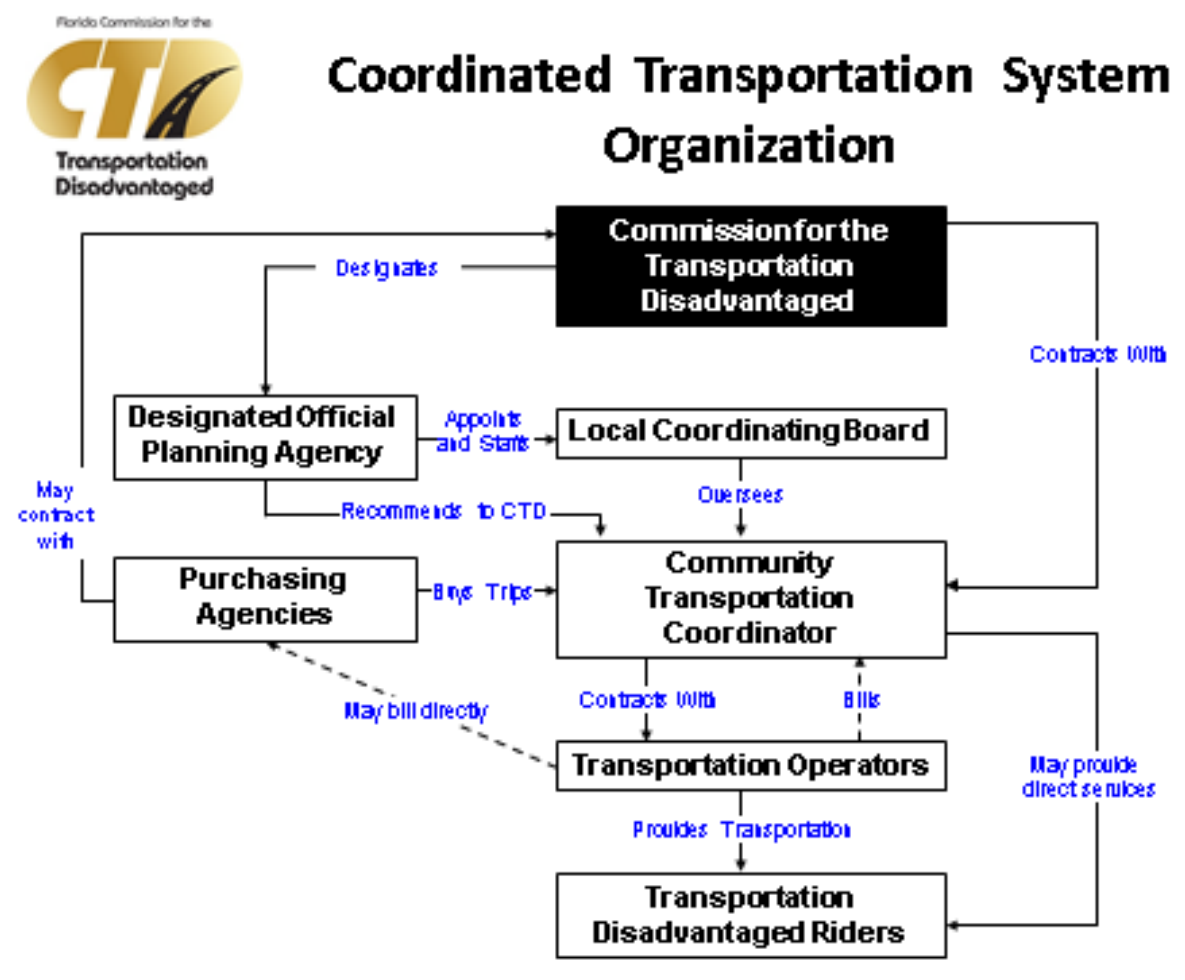

Figure 2-1

Florida Coordinated Transportation System Organization

The CTD approves the CTC for each county based upon the recommendation of the local planning agency. The CTCs are responsible for the provision of transportation services to the TD population within their county. As stated previously, the CTCs must be approved by and enter into a contract (i.e., a Memorandum of Agreement (MOA)) with the CTD. The contract details the minimum service standards and requirements under which the CTC must operate. One of the conditions of the MOA is the development and submittal of a TDSP within 120 days after the execution of the contract.

The TDSP covers a five-year period, with annual updates required for the interim years. The development and submission of the TDSP and annual updates are the joint responsibility of the CTC, the local planning agency, and the LCB.

One required element of the service analysis section of the TDSP is the forecast of the TD population for the service area. The CTD TDSP guidance encouraged the use of the "Methodology Guidelines for Forecasting TD Transportation Demand at the County Level," ${ }^{2}$ which was prepared for the CTD by the University of South Florida's Center for Urban Transportation Research (CUTR) in May 1993. 


\section{Methodology Guidelines for Forecasting TD Transportation Demand at the County Level}

The recommended TD estimate methodology is 20 years old and it predates some significant developments in the Florida public transportation environment, including the implementation of ADA mandated requirements for public transportation service providers.

The maturation of the CTD program, coupled with the changing demographics of Florida over the past two decades, has brought about a need to reassess the applicability and validity of the original 1993 travel demand forecasting methodology.

Factors and circumstances that support the re-examination of the TD forecasting model include:

\section{- Data Availability}

The base requirement of any travel demand forecasting process requires reliable population and demographic data and information on the geographical unit for which the forecast are being generated. One of the goals of this research was to assess the availability of reliable data sources.

Due to changes in the U.S. Census Bureau's data collection procedures the data utilized in the 1993 methodology, particularly data related to the number of persons with a public transportation disability is no longer measured.

Key data requirements for demand forecasting of the defined TD population include the ability to estimate the following:

- Elderly population

- Low income population

- Persons with disabilities

- Transportation disadvantaged populations

- Automobile ownership

- Access to fixed route public transit service

- Access to ADA complementary paratransit service

\section{- Impact of the Americans with Disabilities Act of 1990}

Since the development of the 1993 demand methodology, Federal ADA regulations and policies were put in place and great progress has been made to improve accessibility and mobility for persons with disabilities.

The passage of the ADA and the FTA implementing regulations has produced significant access to and availability of public transportation for persons with disabilities. 
- In the early $1990 \mathrm{~s}$, accessible fixed route buses were virtually non-existent. Today, all public fixed route buses are wheelchair accessible and designed to accommodate most types and sizes of mobility devices.

- In the early 1990s, most fixed route transit agencies limited their services to traditional modes and did not provide any demand responsive services. Instead, paratransit services were viewed primarily as a social service agency responsibility. Today, all fixed route operators are mandated to provide ADA complementary paratransit services for those residents who, due to functional disabilities, are unable to access the fixed route services. Additionally, most public transit agencies now view themselves as mobility managers and now offer a wide range of mobility services.

- In the early 1990 s, the typical infrastructure was not disability friendly and did not accommodate wheelchairs. Travel barriers were the rule and not the exception. Today, communities have implemented curb cuts, wider sidewalks, and other design elements that provide a greatly improved and more pedestrian friendly travel path environment. The result is improved access to public transit facilities and services.

\section{- Original Trip Rate Assumptions}

After estimating overall TD populations, the 1993 demand methodology estimated the annual passenger trips for each of the sub-population groups. The trip demand estimates were calculated by multiplying the group size by trip rates that were derived from a 1988 Urban Mass Transportation Administration (UMTA) study of paratransit demand in the San Francisco area based on an evaluation of seven paratransit systems. The trip rates used to develop general demand were 1.0 or 1.2 trips per month (i.e., 12 or 14.4 annual trips per person) in urban and rural areas, respectively. The difference in rates was a result of an assumption that in urban areas some of the trips would be made on the fixed-route system.

The documentation for the 1993 methodology stated that the use of these trip rates to forecast demand for annual trips was "chosen because the trip rates are based on actual experiences of paratransit systems that are meeting most or all of the trip demand in their service area. ${ }^{3}$ 


\section{- Transportation Disadvantaged Trip Definitions}

The 1993 methodology provided county-level demand forecasts for TD. The methodology was structured around the concept of two different types of transportation disadvantages services - program trips and general trips as defined below:

- "A program trip is one made by a client of a government or social service agency for the purpose of participating in a program of the agency. Examples of program trips are trips to congregate dining facilities, sheltered workshops, job training facilities and Medicaid services.

- A general trip is one made by a transportation disadvantaged person to a destination of his or her choice, not an agency trip. Examples of general trips are trips to work, grocery stores, and recreation areas." ${ }^{4}$

The CTD used the trip types to divide the TD population into two groups:

- Category I TD Population - The Category I population includes all disabled, elderly and low-income persons, and children who are "high-risk" or "at-risk." Most of the Category I children would by definition fall within the disabled and/or the low-income populations.

- Category II TD Population - The eligibility definitions contained in Chapter 427, Florida Statutes require that disabled, elderly, and low-income persons be unable to transport themselves or to purchase transportation. As a result, under the Chapter 427 definition, persons who use TD transportation services for program trips funded by governmental and social service agencies are not necessarily eligible for TD Trust Fund subsidies for general trips. Those persons who are eligible for TD Trust Fund subsidies are referred to as the Category II TD Population." ${ }^{5}$

As displayed in Figure 2-2, Category I population groups include all disabled, elderly and low-income persons, and children who are "high-risk" or "at-risk." As depicted, there are overlaps among the disabled, elderly and low-income populations.

Disability refers to physical or mental limitations that may prevent a person from transporting him or herself, while income refers to the financial capacity of a person to purchase transportation. Similar relationships associated with age that limit mobility are not as apparent. Age alone should not affect a person's ability to transport him or herself. It may, however, relate to other factors that are associated with the aging process or to the demographic characteristics of the elderly population; namely, the higher incidence of disability and poverty among the elderly. 


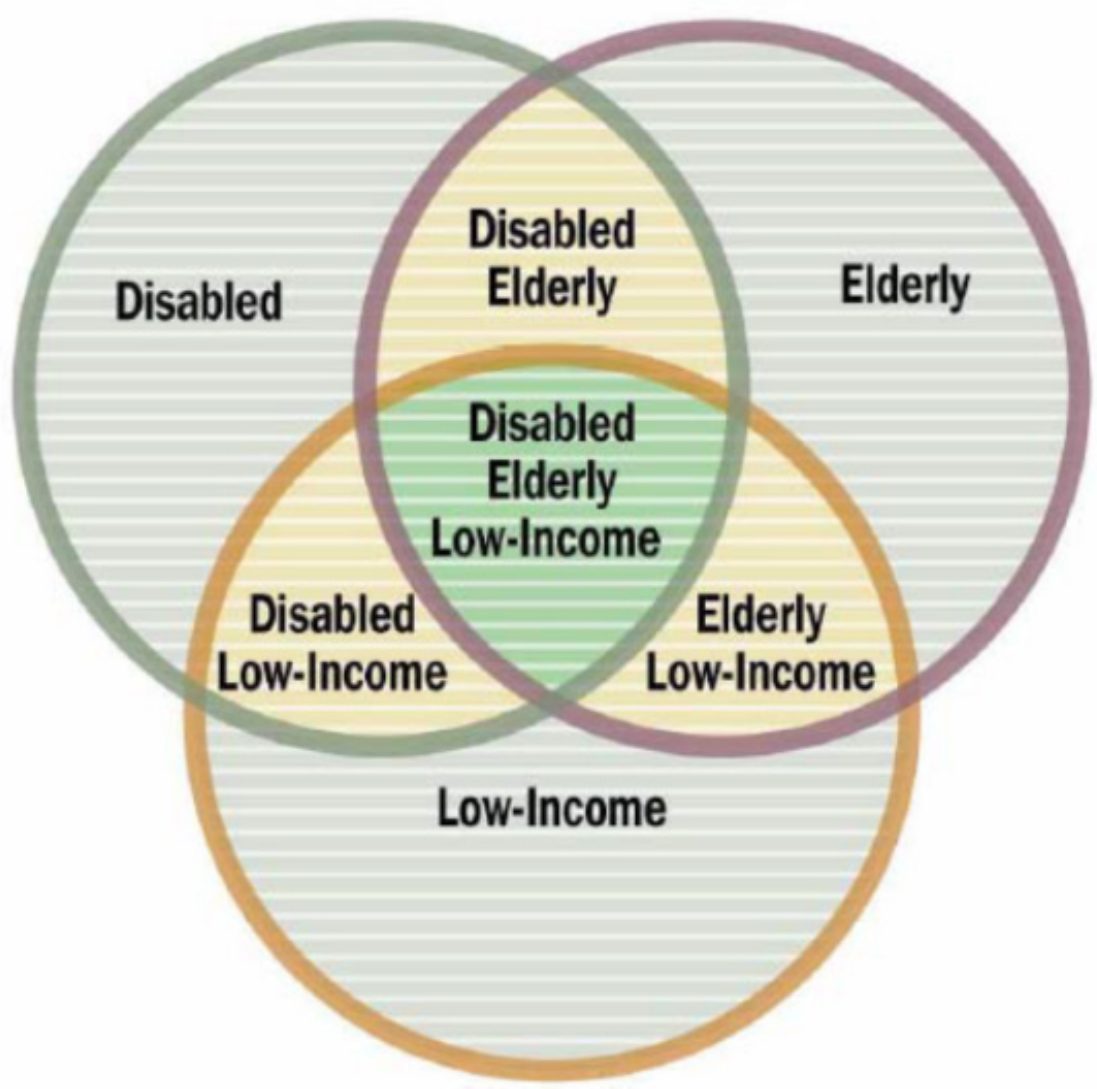

Figure 2-2

Category I Transportation Disadvantaged Population Groups

Therefore, the Chapter 427 definition implies that disability and income status, regardless of age, are the criteria that determine a person's ability to transport themselves, and, thus, the number of persons in the Category II population. ${ }^{6}$

\section{- $\quad$ Florida Medicaid Transportation Changes}

In the decades that have elapsed since the development of these early predictive models, there have been significant developments in the Florida public transportation environment and changes in the Medicaid program. Until recently Medicaid transportation trips were provided in large part by the CTCs. The Medicaid transportation funding was "capped" at an annual dollar amount, but all requested trips were required to be performed. As a result, several CTCs have opted out of providing Medicaid transportation trips. The Florida Medicaid program is currently changing to a managed care program in which the assignment of the Medicaid trips will no longer be controlled or managed by the CTD or CTCS. 


\section{Other Paratransit Demand Methodologies}

At the beginning of this research effort, a literature review was conducted to identify methodologies and findings from prior studies that could be adapted for the TD demand forecasting methodology.

The literature review was conducted using the "Transport Research International Documentation" system, which combines the records from the Transportation Research Board's Transportation Research Information Services and the Joint Transport Research Centre's International Transport Research Documentation databases.

The literature review revealed the limited availability of research and documentation of travel demand forecasting tools that are relevant to Florida. The initial documents, from the 1980s and 1990s, were fairly simple manual approaches based on observations of ridership experiences in typical community paratransit systems. This approach assumed that under similar conditions, other communities could expect to encounter similar ridership responses. These non-computer simulation approaches were developed to provide simple, straightforward methods to estimate expected ranges of trip types and numbers.

How to Predict and Control Ridership for Community Transportation Systems - A Ridership Manual ${ }^{7}$ was one of the earliest attempts to provide human service agencies a means to estimate ridership and effectively respond to anticipated ridership through modifications to the way in which transportation services were provided.

The report included ridership and demand estimates "based on heuristic analogous measures." This esoteric term simply means that the manual used actual, empirical ridership experiences of other systems to suggest the conditions under which similar agencies would probably encounter the same ridership response. ${ }^{8}$ This non-computer simulation approach was intended to provide a simple, straightforward approach that would provide agencies with a range of trip types and numbers that could be expected based on the characteristics of the community and the agency clients. This methodology was based on simple calculations based on both "multiple regression analysis and in part on intuition guided by logic and experience." ${ }^{9}$

Chapter Two of the manual focused on expected ridership levels (i.e., travel demand). The approach converted observed ridership patterns into simple prediction methods. Simplified relationships and easily measured variables were used as proxies to avoid the need for large amounts of detailed data and sophisticated modeling efforts.

This methodology forecasted potential riders by groups: elderly, low income, and all handicapped persons (i.e., today referred to as persons with disabilities) using U.S. Census data and national averages. 


\section{Transit Cooperative Research Project (TCRP) Report 119: Improving ADA} Complementary Paratransit Demand Estimation ${ }^{10}$ provides a handbook for estimating ADA paratransit demand. The handbook presents estimation tools derived from a statistical model developed from data collected from "representative systems." "The tools for estimating the demand for ADA complementary paratransit included (1) an Excel spreadsheet that calculates the demand estimates using user-entered data indicating a system's policies and service area characteristics; (2) a series of graphs for determining factors from which the demand estimates can be calculated by hand; and (3) elasticities and change factors for quick calculations about small differences between systems and the impacts of small changes to service policies." ${ }^{11}$

The demand estimation tools take into account six key variables that impact ridership:

1. "ADA paratransit service area population.

2. Base fare for ADA paratransit.

3. Percent of applicants for ADA paratransit found conditionally eligible.

4. Whether or not trip-by-trip eligibility based on conditions of eligibility are used.

5. Percent of service area population with household incomes below the poverty level.

6. The effective window used to determine on-time performance. ${ }^{12}$

This report presents several tools that may be used to estimate the demand for paratransit services for individuals, who because of their disabilities are unable to use the fixed route system. The tools are designed to estimate demand that is consistent with the legal requirements of the ADA in terms of level of services requirements and regulations.

Building upon TCRP Report 119, the recently released TCRP Report 158: Improving ADA Paratransit Demand Estimation: Regional Modeling ${ }^{13}$ created two models that permit more detailed forecasts to deepen understanding of the travel behavior of ADA paratransit eligible people. Both models are based on analysis of a survey of 800 users of ADA paratransit service operated by Dallas Area Rapid Transit and the Fort Worth Transportation Authority.

The sketch planning model allows a planner to enter a small number of variables by means of a spreadsheet interface to explore how these variables affect predicted trip-making on ADA paratransit and other modes in the Dallas-Fort Worth area. Although these forecasts are limited to the Dallas-Fort Worth area they allow exploration of hypothetical changes in age profile, income, household size, travel times, on-time performance, and fares within the Dallas-Fort Worth area. The sketch planning model is limited to predictions of travel by people already registered as eligible to use ADA paratransit.

The regional planning model (actually a system of multiple models) can be adapted to provide forecasts tailored to conditions in other metropolitan areas. This model system also includes the effects of changes in demographic and travel variables on registration (application and determination of eligibility) to use ADA paratransit. 
To apply the regional planning model system to another area, planners need census tractlevel socioeconomic data, employment data by census tract or travel analysis zone, and matrices of zone-to-zone travel times and distances for whatever year a forecast is desired. It is also necessary to incorporate differences in the characteristics of the ADA paratransiteligible population. This could be done by collecting new survey data on the local ADA paratransit-eligible population or by adjusting "expansion weights" in the Dallas-Fort Worth sample to match the local ADA-eligible population. The latter can be done with any data that the local operator has on the riders (probably just age distribution), as well as census comparisons of regional demographic distributions with those in Dallas-Fort Worth, such as adjusting the percentage below the poverty rate. Without such data, the regional planning model can still be used for exploratory analysis, but is limited to the Dallas-Fort Worth region.

\section{Alternative Model Development Considerations}

With the growing population of seniors and people with disabilities seeking more mobility opportunities, there needs to be an up-to-date toolkit for Florida transportation agencies to forecast demand for TD customer markets. This information is critical for transit planners and operators to interpret service demands and translate those into operating and capital program needs and priorities.

These changes necessitate a re-examination of the original trip definitions and TD population categories used by the CTD to determine if they are still relevant and meaningful.

In the development of a new approach for the estimation of paratransit service demand, several considerations were taken into account including:

- There is a need to strike a balance between simplicity and complexity to account for the different end users. The demand estimation model should be applicable to all of Florida's 67 counties. The availability of planning staff resources and their skill sets and sophistication may vary. The new model approach should to be useable and understandable for all end users.

- The model should be able to account for various TD mobility options - including the traditional TD trips, ADA complementary trips, special needs trips, specific program or agency sponsored trips, senior mobility needs and the use of traditional fixed route services.

- The demand estimation approach needs to account for the growing senior population as the "baby boomers" begin to retire. This would include balancing the growing number of seniors with their healthier and more affluent life styles.

- The model must be able to adjust to the anticipated travel demand impacts placed on communities and local CTCs in Florida. As a result of the changes in the Medicaid program, Medicaid sponsored trips will no longer be directly managed by the CTCs. 
- The emerging mobility management approach to look at the community's mobility needs in a more holistic way will positively impact the delivery of TD services and help distribute the TD demand over several potential service providers.

As a result of these factors and to take advantage of current source data, it is recommended that the CTD move away from the traditional transportation definitions of trip type and category. Instead of using the terminology from the 1993 methodology to describe trip types (e.g., program trip or general trip) and trip categories (Category I and II), the proposed new methodology first defines the "general TD" population. The general TD population includes the estimates of all disabled, elderly and low-income persons and children who are "high-risk" or "at-risk" definition.

These population groups are further refined to identify the "critical need TD" population. The critical need TD population includes individuals who due to severe physical limitations or low incomes are unable to transport themselves or purchase transportation, and are dependent upon others to obtain access to health care, employment, education, shopping, social activities, or other life sustaining activities. 


\section{Chapter 3 \\ Paratransit Service Demand Estimation Tool}

To serve as an aid in the development of TD population and travel demand estimates, a spreadsheet tool was developed. It was designed in a way that enables users to input the most current U.S. Census Bureau demographic and socio-economic data available. Once the user input is complete, a series of formulas are used to project future travel demand.

This chapter describes how the U.S. Census Bureau's ACS data will be used to calculate the general TD population and specific sub-populations. Step-by-step instructions are included to allow a user to easily access the ACS data and complete the user input spreadsheet fields. Examples of the completed demand estimate spreadsheets are presented along with an explanation of other demand methodology assumptions and data sources used in the methodology.

\section{U.S. Census Data Overview}

Until recently, data from the Decennial Census (conducted every 10 years during all years ending in " 0 ") have been utilized for a variety of transportation planning and demand estimation applications. The Decennial Census has collected basic data on characteristics such as age, gender and race using a "short form" distributed to all U.S. households. This information was supplemented with a "long form" survey distributed to approximately one in six households to collect more detailed social and economic characteristics.

The 2010 Census was the first year since 1940 that a long form was not utilized. The more detailed social, demographic and economic information once collected via the long form survey was replaced with the Census Bureau's ACS beginning in 2005. This survey involves the continuous collection of data from a small percentage of the population on a rotating basis each year versus every ten years.

The ACS data will be utilized as the foundation for the methodology guidelines presented for forecasting transportation demand for Florida's paratransit market segments. While the ACS is subject to a wider margin of sampling error due to the smaller sample size versus the Decennial Census, it offers an advantage in terms of providing a more current data source that can reflect the quickly changing demographics of Florida's population; a feature not previously available in the adopted tool "Methodology Guidelines for Forecasting TD Transportation Demand at the County Level."

The most current ACS data available as of early 2013 are 1 year estimates (2011) for areas with a population of 65,000 and above, 3 year estimates (2009-2011) for areas with a population of 20,000 and above, and 5 year estimates (2007-2011) for all other areas. Table 3-1 displays the distinguishing characteristics of each of the data sets to aid in the selection of the appropriate data set for a particular application. 
Table 3-1

Distinguishing Features of ACS Data Sets

\begin{tabular}{|c|c|c|}
\hline 1-year estimates & 3-year estimates & 5-year estimates \\
\hline 12 months of collected data & 36 months of collected data & 60 months of collected data \\
\hline $\begin{array}{l}\text { Data for areas with populations of } \\
65,000+\end{array}$ & $\begin{array}{l}\text { Data for areas with populations of } \\
20,000+\end{array}$ & Data for all areas \\
\hline Smallest sample size & Larger sample size than 1 -year & Largest sample size \\
\hline Less reliable than 3-year or 5-year & $\begin{array}{l}\text { More reliable than } 1 \text {-year; less reliable } \\
\text { than } 5 \text {-year }\end{array}$ & Most reliable \\
\hline Most current data & $\begin{array}{l}\text { Less current than } 1 \text {-year estimates; } \\
\text { more current than } 5 \text {-year }\end{array}$ & Least current \\
\hline Best used when & Best used when & Best used when \\
\hline $\begin{array}{l}\text { Currency is more important than } \\
\text { precision }\end{array}$ & $\begin{array}{l}\text { More precise than } 1 \text {-year, more } \\
\text { current than } 5 \text {-year }\end{array}$ & $\begin{array}{l}\text { Precision is more important than } \\
\text { currency }\end{array}$ \\
\hline Analyzing large populations & $\begin{array}{l}\text { Analyzing smaller populations } \\
\text { Examining smaller geographies } \\
\text { because } 1 \text {-year estimates are not } \\
\text { available }\end{array}$ & $\begin{array}{l}\text { Analyzing very small populations } \\
\text { Examining tracts and other smaller } \\
\text { geographies because } 1 \text {-year } \\
\text { estimates are not available }\end{array}$ \\
\hline
\end{tabular}

Source: U.S. Census Bureau Website

In 2011, there were 154,466 Florida addresses initially selected for the ACS sample. Each year's sample is divided into 12 monthly samples for the ACS. The initial sample includes addresses later determined to be commercial or nonexistent, as well as housing units that are not interviewed due to subsampling for personal visit follow-up, refusals or other reasons. Ultimately there were 95,657 housing units sampled (via mail, telephone or personal visit between January 1 and December 31, 2011).

As previously described, the three census data sets used to measure Florida's TD population are age, income and disability. While the measurement of age and income for most geographical units is a relatively simple process using ACS data, the concept of disability has evolved over time, resulting in various definitions that are subject to interpretation and eligibility, particularly as it relates to the provision of transportation services.

As public perception of disability has changed, so have the goals of programs supporting people with disabilities. In the past, the emphasis was to provide support to people with disabilities primarily through cash benefits and other replacements to earned income. Today, the emphasis has shifted to supporting independence and promoting involvement in all aspects of society.

The Census Bureau and other federal agencies that collect data about individuals with disabilities face two primary challenges:

- The process of measuring a complex, multi-dimensional concept in a survey format is difficult. 
- The constantly evolving concepts and perceptions of disability require survey professionals to continuously develop measurement approaches that adapt to new definitions.

The Census Bureau has responded by making modifications to its long and short form surveys as described below.

The 1990 Decennial Census Sample Survey (Long-form) included two questions with 2 subparts each with which to identify people with disabilities. They were as follows:

18. Does this person have a physical, mental, or other health condition that has lasted for 6 or more months and which:

a. Limits the kind or amount of work this person can do at a job?

b. Prevents this person from working at a job?

19. Because of a health condition that has lasted for 6 or more months, does this person have any difficulty:

a. Going outside the home alone, for example, to shop or visit a doctor's office?

b. Taking care of his or her own personal needs, such as bathing, dressing, or getting around inside the home?

The 2000 Decennial Census Sample Survey (Long-form) included 2 questions with a total of six subparts with which to identify people with disabilities. The data on disability status were derived from answers to long-form questionnaire items 16 and 17 . The questions were as follows:

16. Does this person have any of the following long-lasting conditions:

a. Blindness, Deafness, or severe vision or hearing impairments?

b. A condition that substantially limits one or more basic physical activities such as walking, climbing stairs, reaching, lifting, or carrying?

17. Because of a physical, mental or emotional condition lasting 6 months or more, does this person have any difficulty in doing any of the following activities:

a. Learning, remembering, or concentrating?

b. Dressing, bathing, or getting around inside the home?

c. (ANSWER IF THIS PERSON IS 16 YEARS OLD OR OVER) Going outside the home alone to shop or visit a doctor's office?

d. (ANSWER IF THIS PERSON IS 16 YEARS OLD OR OVER) Working at a job or business?

As shown in Figure 3-1, the ACS instrument now includes 6 questions that are designed to measure disability. However, the presence of a disability does not necessarily mean an individual needs specialized paratransit services, nor does it mean that the individual meets the paratransit eligibility criteria based on a transportation provider's policies. 

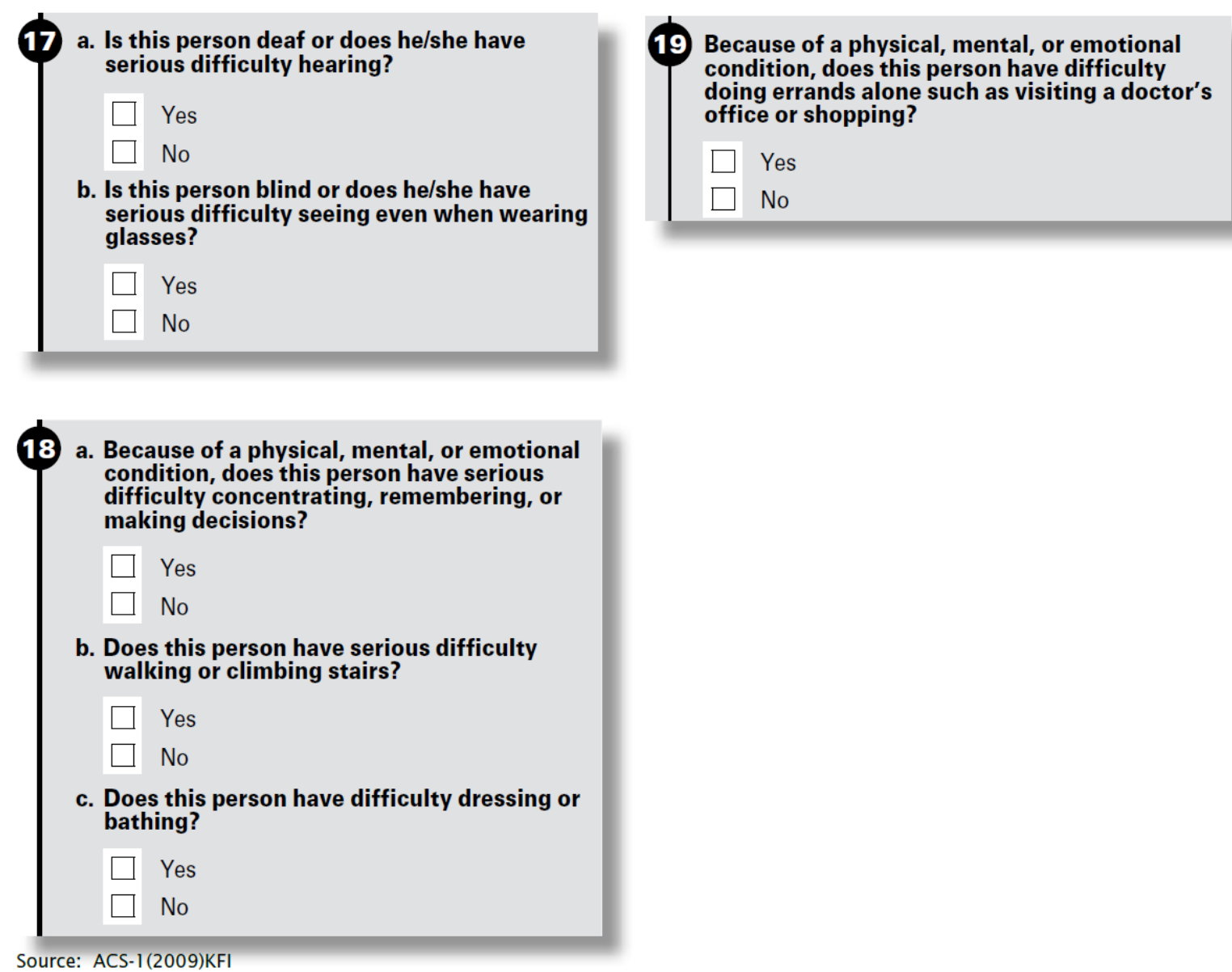

Figure 3-1

American Community Survey Questions Designed to Measure Disability 


\section{Data Input Guidance}

As a result of this research effort, a new TD demand spreadsheet tool was developed which utilizes more current data and assumptions. The TD demand spreadsheet tool first requires some user generated input. An image of the user input spreadsheet tab are shown in Tables 3-2 and 3-3. Instructions for accessing and preparing the input information are provided.

Step 1 - Populate the yellow fields on the data input tab on the spreadsheet. Insert the name of the area you are analyzing, the last year of the U.S Census data set you wish to use (based on the characteristics previously described in Table 4-1), the percent of your service area population (within the selected geography) with access to fixed route transit, and the number of days your demand response service operates.

In the example that follows, demand estimates for Indian River County are presented. Eighty five percent of the population in Indian River County has access to fixed-route transit and paratransit service operates 365 days per year. 3-year (2009-2011) Census data are used as inputs.

Table 3-2

Spreadsheet Tool Sample Data Input Table

Yellow cells indicate required data input

Area Name: Indian River County

Last Year of Census Data Used: 2011

Percent Transit Coverage: $\quad \mathbf{8 5 \%}$

Number of Annual Service Days: 365 
Step 2 - Identify source for current population projections. In this example medium projections of Florida population by county (2011-2040) published by the Bureau of Economic and Business Research (BEBR) at the University of Florida are displayed in yellow. See Appendix A.

Insert the population projections in the data input table.

Table 3-3

BEBR County Population Projections

\begin{tabular}{|c|c|}
\hline \multicolumn{2}{|c|}{$\begin{array}{c}\text { County Population } \\
\text { Projections }\end{array}$} \\
\hline 2015 & $\mathbf{1 4 5}, \mathbf{6 1 3}$ \\
\hline 2020 & $\mathbf{1 5 8}, \mathbf{5 0 1}$ \\
\hline 2025 & $\mathbf{1 7 0}, \mathbf{9 3 1}$ \\
\hline 2030 & $\mathbf{1 8 2}, \mathbf{5 8 4}$ \\
\hline 2035 & $\mathbf{1 9 3}, \mathbf{9 5 2}$ \\
\hline 2040 & $\mathbf{2 0 4}, \mathbf{1 3 4}$ \\
\hline
\end{tabular}

\section{American Community Survey}

ACS age, income, and disability data are used in the next steps of the methodology for estimating Florida's TD population at the county level. The following sections detail how to access the ACS and obtain the demographic data required for input to the paratransit service demand estimation tool.

While the following methodology can be used at the county level for most Florida counties using 1-, 3- or 5-year data samples, the 5-year data set must be used for counties with a population of generally 20,000 or less since ACS data are currently limited by an absence of disability data at the county level.

Disability data at the county level for the smaller counties will be included when the Census Bureau releases its new 5-year estimates in late 2013, at which time the standard methodology can be used by all counties (using either the 1- or 3-year data set for counties with a population of 20,000 or more or 5-year data for counties with a population of 20,000 or less). In the interim, a slightly modified approach to capture the required input will be described for Florida counties with a population of approximately 20,000 or less.

Due to the relatively small ACS annual sample size and changes in the ACS survey instrument between 2008 and 2009, the Census Bureau will not publish county level disability statistics until five years of disability data has been collected (late 2013). Instead, multiple counties in Florida have been grouped into Public Use Microdata Areas (PUMAs) of approximately 100,000 in population to estimate regional disability statistics. The regional estimates can be applied to estimate county level disability data. 
Until the new 5-year estimates are released in late 2013, smaller counties included in one of the four PUMAs (detailed below) should complete Step 3, skip Steps 4 through 6, and go directly to Steps 7 through 14 to complete data collection. All others should proceed to Steps 4 through 6.

The twelve counties in Florida with a 2011 population of approximately 20,000 or less are grouped into one of four PUMAs as shown below:

- PUMA 00400 - Holmes

- PUMA 00600 - Calhoun, Franklin, Gulf, Jefferson, Liberty, Madison

- PUMA 00800 - Dixie, Gilchrist, Hamilton, Lafayette

- PUMA 00900 - Union

Step 3 - Access the Census Bureau's American FactFinder for ACS data and click "get data" at http://factfinder2,census,gov/faces/nav/jsf/pages/index.xhtml

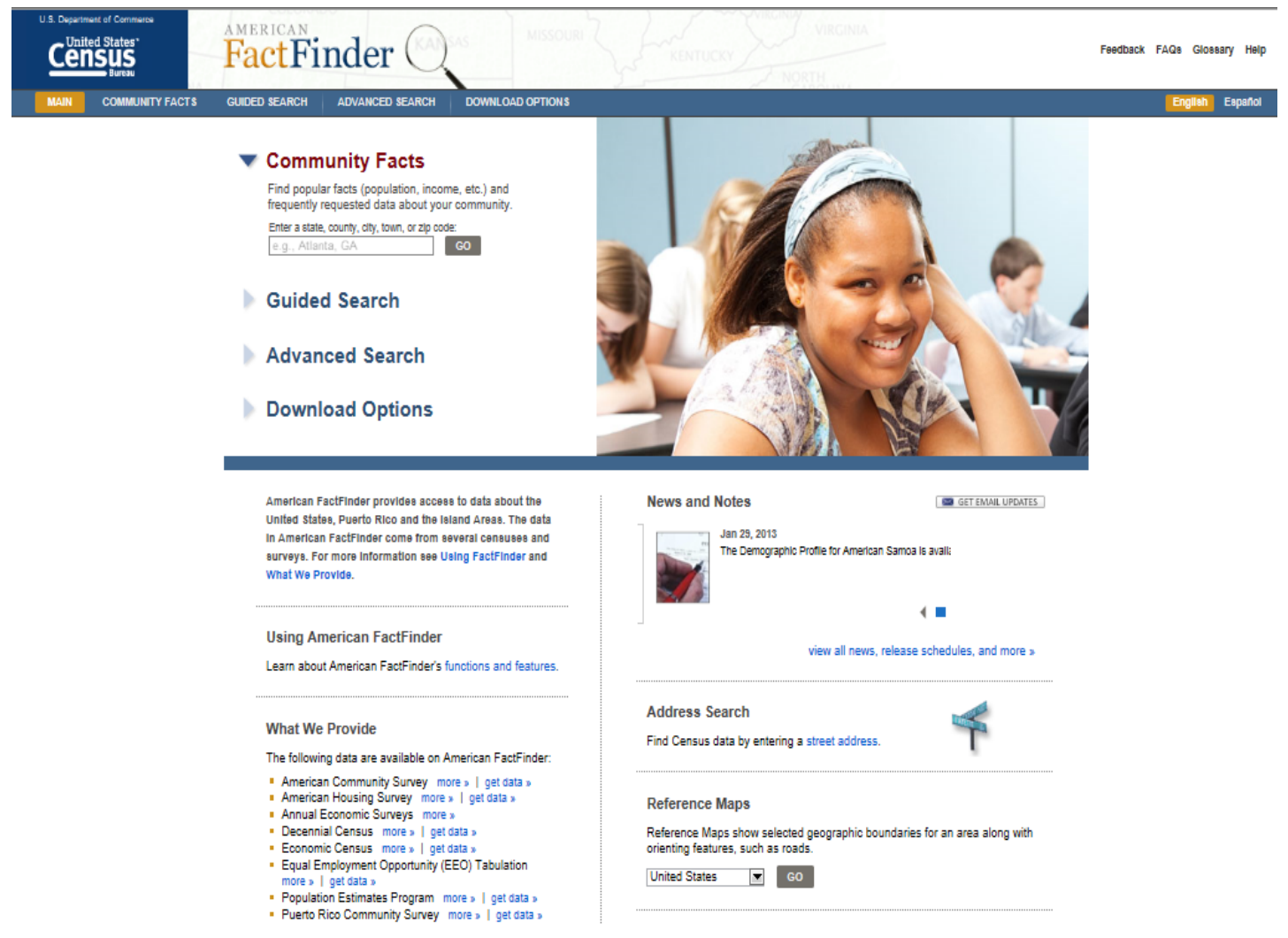


Step 4 - Type in table number B18130. Type in the selected geography. Click "go." Indian River County is used in this example.

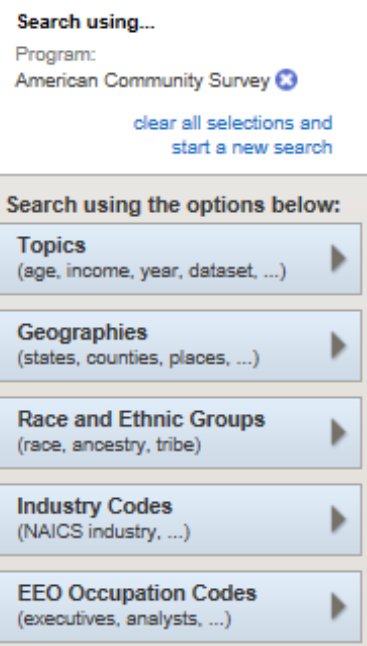

(executives, эnstyst


Step 5 - Using the same data set previously selected for the Step 1 data entry page (in this example 2009-2011) check table number B18130. Click "view." In this example, the 3-year data set has been selected.

\begin{tabular}{|c|c|c|c|c|}
\hline & ID $\Leftrightarrow$ & Table, File or Document Title & Dataset & About \\
\hline 回 & B18130 & AGE BY DISABILITY STATUS BY POVERTY STATUS & 2008 ACS 1-year estimates & (i) \\
\hline 口 & B18130 & AGE BY DISABILITY STATUS BY POVERTY STATUS & 2009 ACS 1-year estimates & (i) \\
\hline 口 & $B 18130$ & AGE BY DISABIUTY STATUS BY POVERTY STATUS & 2010 ACS 3-year estimates & ( \\
\hline 回 & B18130 & AGE BY DISABILITY STATUS BY POVERTY STATUS & 2010 ACS 1-year estimates & ( \\
\hline 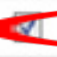 & B18130 & AGE BY DISABILITY STATUS BY POVERTY STATUS & 2011 ACS 3-year estimates & \\
\hline 口 & $B 18130$ & AGE BY DISABIUTY STATUS BY POVERTY STATUS & 2011 ACS 1-year estimates & ( \\
\hline
\end{tabular}

The following table will be displayed:

\begin{tabular}{|c|c|c|}
\hline & \multicolumn{2}{|c|}{ Indian River County, Florida } \\
\hline & Estimate & Margin of Error \\
\hline Total: & 136,400 & $+1-435$ \\
\hline Under 5 years: & 6,317 & $+l-205$ \\
\hline With a disability: & 0 & $+l-135$ \\
\hline Income in the past 12-months below poverty level & 0 & $+1-135$ \\
\hline Income in the past 12-months at or above poverty level & 0 & $+j-135$ \\
\hline No disability: & 6,317 & $+l-205$ \\
\hline Income in the past 12-months below poverty level & 1,703 & $+1-486$ \\
\hline Income in the past 12-months at or above poverty level & 4,614 & $+1-526$ \\
\hline 5 to 17 years: & 19,110 & $+1-200$ \\
\hline With a disability: & 859 & $+1-292$ \\
\hline Income in the past 12-months below poverty level & 304 & $+l-149$ \\
\hline Income in the past 12-months at or above poverty level & 555 & $+1-237$ \\
\hline No disability: & 18,251 & $+1-313$ \\
\hline Income in the past 12-months below poverty level & 4,348 & $+1-874$ \\
\hline Income in the past 12-months at or above poverty level & 13,903 & $+1-937$ \\
\hline 18 to 34 years: & 21,258 & $+1-338$ \\
\hline With a disability: & 1,372 & $+1-443$ \\
\hline Income in the past 12-months below poverty level & 357 & $+i-206$ \\
\hline Income in the past 12-months at or above poverty level & 1,015 & $+1-386$ \\
\hline No dissbility: & 19,886 & $+1-527$ \\
\hline Income in the past 12-months below poverty level & 3,851 & $+1-658$ \\
\hline Income in the past 12-months at or above poverty level & 16,035 & $+1-871$ \\
\hline 35 to 64 years: & 52,185 & $+1-382$ \\
\hline With a disability: & 6,308 & $+1-810$ \\
\hline Income in the past 12-months below poverty level & 1,815 & $+1-508$ \\
\hline Income in the past 12-months at or sbove poverty level & 4,493 & $+j-653$ \\
\hline No disability: & 45,887 & $+1-852$ \\
\hline Income in the past 12-months below poverty level & 5,005 & $+1-854$ \\
\hline Income in the past 12-months at or above poverty level & 40,882 & $+/-1,158$ \\
\hline 65 to 74 years: & 18,050 & $+1-288$ \\
\hline With a disability: & 2,789 & $+1-411$ \\
\hline Income in the past 12-months below poverty level & 482 & $+1-239$ \\
\hline Income in the past 12-months at or sbove poverty level & 2,327 & $+1-390$ \\
\hline No disability: & 15,281 & $+1-454$ \\
\hline Income in the past 12-months below poverty level & 906 & $+1-404$ \\
\hline Income in the past 12-months at or above poverty level & 14,355 & $+1-503$ \\
\hline 75 years and over: & 19,470 & $+1-324$ \\
\hline With a disability: & 8,744 & $+1-711$ \\
\hline Income in the past 12-months below poverty level & 887 & $+j-336$ \\
\hline Income in the past 12-months at or above poverty level & 7,857 & $+f-731$ \\
\hline No disability: & 10,726 & $+1-618$ \\
\hline Income in the past 12-months below poverty level & 587 & $+1-188$ \\
\hline Income in the past 12-months at or above poverty level & 10,159 & $+1-620$ \\
\hline
\end{tabular}


Step 6 - Using the information from the previous table (Age by Poverty Status by Disability) insert (a) total population by age (b) population below poverty level by age (c) total population with a disability by age and (d) total population with a disability and below the poverty level in the data input spreadsheet sections displayed in yellow as shown below.

Table 3-4

Required County Population Data Input

\begin{tabular}{|l|r|r|r|r|}
\hline $\begin{array}{c}\text { County } \\
\text { Population By } \\
\text { Age }\end{array}$ & $\begin{array}{c}\text { Total Pop by } \\
\text { Age }\end{array}$ & $\begin{array}{c}\text { Population } \\
\text { Below Poverty } \\
\text { Level by Age }\end{array}$ & $\begin{array}{c}\text { Total } \\
\text { Population with } \\
\text { a Disability by } \\
\text { Age }\end{array}$ & $\begin{array}{c}\text { Total Pop with } \\
\text { Disability and } \\
\text { Below Poverty } \\
\text { Level by Age }\end{array}$ \\
\hline$<5$ Years of Age & $\mathbf{6 , 3 1 7}$ & $\mathbf{1 , 7 0 3}$ & $\mathbf{0}$ & $\mathbf{0}$ \\
$5-17$ & $\mathbf{1 9 , 1 1 0}$ & $\mathbf{4 , 6 5 2}$ & $\mathbf{9 0 1}$ & $\mathbf{3 0 4}$ \\
$18-34$ & $\mathbf{2 1 , 2 5 8}$ & $\mathbf{4 , 2 0 8}$ & $\mathbf{1 , 3 7 2}$ & $\mathbf{3 5 7}$ \\
$35-64$ & $\mathbf{5 2 , 1 9 5}$ & $\mathbf{6 , 8 4 5}$ & $\mathbf{6 , 3 0 8}$ & $\mathbf{1 , 8 1 5}$ \\
\hline Total Non Elderly & 98,880 & 17,408 & 8,581 & 2,476 \\
\hline $65-74$ & $\mathbf{1 8 , 0 5 0}$ & $\mathbf{1 , 3 6 8}$ & $\mathbf{2 , 7 8 9}$ & $\mathbf{4 6 2}$ \\
$75+$ & $\mathbf{1 9 , 4 7 0}$ & $\mathbf{1 , 4 5 4}$ & $\mathbf{8 , 7 4 4}$ & $\mathbf{8 8 7}$ \\
\hline Total Elderly & 37,520 & 2,822 & 11,533 & 1,349 \\
\hline Total & 136,400 & 20,230 & 20,114 & 3,825 \\
\hline
\end{tabular}

Step 6 completes all user required input for the Florida counties with populations of over 20,000 . Continue to page 32 for an explanation of the next steps in the demand methodology. 
Steps 7 through 14 detail the slightly modified approach of accessing the input data for Florida counties with a population of approximately 20,000 or less.

Step 7 - Type table number B01001 (Sex by Age). Type selected geography. Click "go." In this example Holmes County Florida is the selected geography.

\begin{tabular}{|c|c|c|c|c|c|}
\hline \multirow{3}{*}{$\begin{array}{l}\text { Search using... } \\
\text { Program: } \\
\text { American Community Survey } \mathbb{} \\
\text { clear all selections and } \\
\text { start a new search }\end{array}$} & \multicolumn{5}{|c|}{ Refine your search results: B01001 } \\
\hline & & & (-) topics $\bigcirc$ race/ancestry $\bigcirc$ industries & occupations & \\
\hline & \multicolumn{2}{|c|}{1 Selected: } & D. Download | Compare | & $?$ & \\
\hline Search using the options below: & & & Table, File or Document Title & Dataset & About $>2$ \& \\
\hline \multirow{2}{*}{$\begin{array}{l}\text { Topics } \\
\text { (age, income, year, dataset, ...) }\end{array}$} & $\square$ & $\mathrm{DP} 02$ & SELECTED SOCIAL CHARACTERISTICS IN THE UNITED STATES & 2011 ACS 1-vear estimates & A \\
\hline & 回 & & 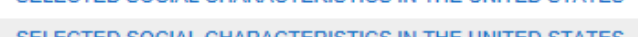 & & \\
\hline \multirow{2}{*}{$\begin{array}{l}\text { Geographies } \\
\text { (states, counties, places, ...) }\end{array}$} & $\square$ & DP02 & SELECTED SOCIAL CHARACTERISTICS IN THE UNITED STATES & 2011 ACS 3-year estimates & (2) \\
\hline & $\square$ & DP02 & SELECTED SOCIAL CHARACTERISTICS IN THE UNITED STATES & 2011 ACS 5-year estimates & (i) \\
\hline \multirow{2}{*}{$\begin{array}{l}\text { Race and Ethnic Groups } \\
\text { (race, ancestry, tribe) }\end{array}$} & $\square$ & DP02PR & SELECTED SOCIAL CHARACTERISTICS IN PUERTO RICO & 2011 ACS 1-year estimates & (i) \\
\hline & $\square$ & DP02PR & SELECTED SOCIAL CHARACTERISTICS IN PUERTO RICO & 2011 ACS 3-year estimates & (i) \\
\hline \multirow{2}{*}{$\begin{array}{l}\text { Industry Codes } \\
\text { (NAICS industry, ...) }\end{array}$} & $\square$ & DP02PR & SELECTED SOCIAL CHARACTERISTICS IN PUERTO RICO & 2011 ACS 5-year estimates & (i) \\
\hline & $\square$ & DP03 & SELECTED ECONOMIC CHARACTERISTICS & 2011 ACS 1-year estimates & (i) \\
\hline \multirow{19}{*}{$\begin{array}{l}\text { EEO Occupation Codes } \\
\text { (executives, analysts, ...) }\end{array}$} & $\square$ & DP03 & SELECTED ECONOMIC CHARACTERISTICS & 2011 ACS 3-year estimates & (i) \\
\hline & $\square$ & DP03 & SELECTED ECONOMIC CHARACTERISTICS & 2011 ACS 5-year estimates & (i) \\
\hline & $\square$ & DP04 & SELECTED HOUSING CHARACTERISTICS & 2011 ACS 1-year estimates & (i) \\
\hline & 目 & DP04 & SELECTED HOUSING CHARACTERISTICS & 2011 ACS 3-year estimates & (i) \\
\hline & $\square$ & DP04 & SELECTED HOUSING CHARACTERISTICS & 2011 ACS 5-year estimates & i \\
\hline & $\square$ & DP05 & ACS DEMOGRAPHIC AND HOUSING ESTIMATES & 2011 ACS 1-year estimates & (i) \\
\hline & $\square$ & DP05 & ACS DEMOGRAPHIC AND HOUSING ESTIMATES & 2011 ACS 3-year estimates & i \\
\hline & $\square$ & DP05 & ACS DEMOGRAPHIC AND HOUSING ESTIMATES & 2011 ACS 5-year estimates & i \\
\hline & $\square$ & $\mathrm{CP} 02$ & SELECTED SOCIAL CHARACTERISTICS IN THE UNITED STATES & 2011 ACS 1-year estimates & (i) \\
\hline & $\square$ & CP02PR & SELECTED SOCIAL CHARACTERISTICS IN PUERTO RICO & 2011 ACS 1-year estimates & i \\
\hline & $\square$ & $\mathrm{CP} 03$ & SELECTED ECONOMIC CHARACTERISTICS & 2011 ACS 1-year estimates & (i) \\
\hline & $\square$ & $\mathrm{CP} 04$ & SELECTED HOUSING CHARACTERISTICS & 2011 ACS 1-year estimates & i \\
\hline & $\square$ & CP05 & ACS DEMOGRAPHIC AND HOUSING ESTIMATES & 2011 ACS 1-year estimates & (i) \\
\hline & $\square$ & NP01 & Population and Housing Narrative Profile: 2011 & 2011 ACS 1-year estimates & (i) \\
\hline & $\square$ & NP01 & Population and Housing Narrative Profile: 2009-2011 & 2011 ACS 3-year estimates & (i) \\
\hline & $\square$ & S0101 & AGE AND SEX & 2011 ACS 1-year estimates & (i) \\
\hline & $\square$ & S0101 & AGE AND SEX & 2011 ACS 3-year estimates & i \\
\hline & $\square$ & S0101 & AGE AND SEX & 2011 ACS 5-year estimates & (i) \\
\hline & & 量 & $\square$ Compare $\square$ Clear All & ) & \\
\hline
\end{tabular}


Step 8 - Check table number B01001 5 year data set. Click "view."

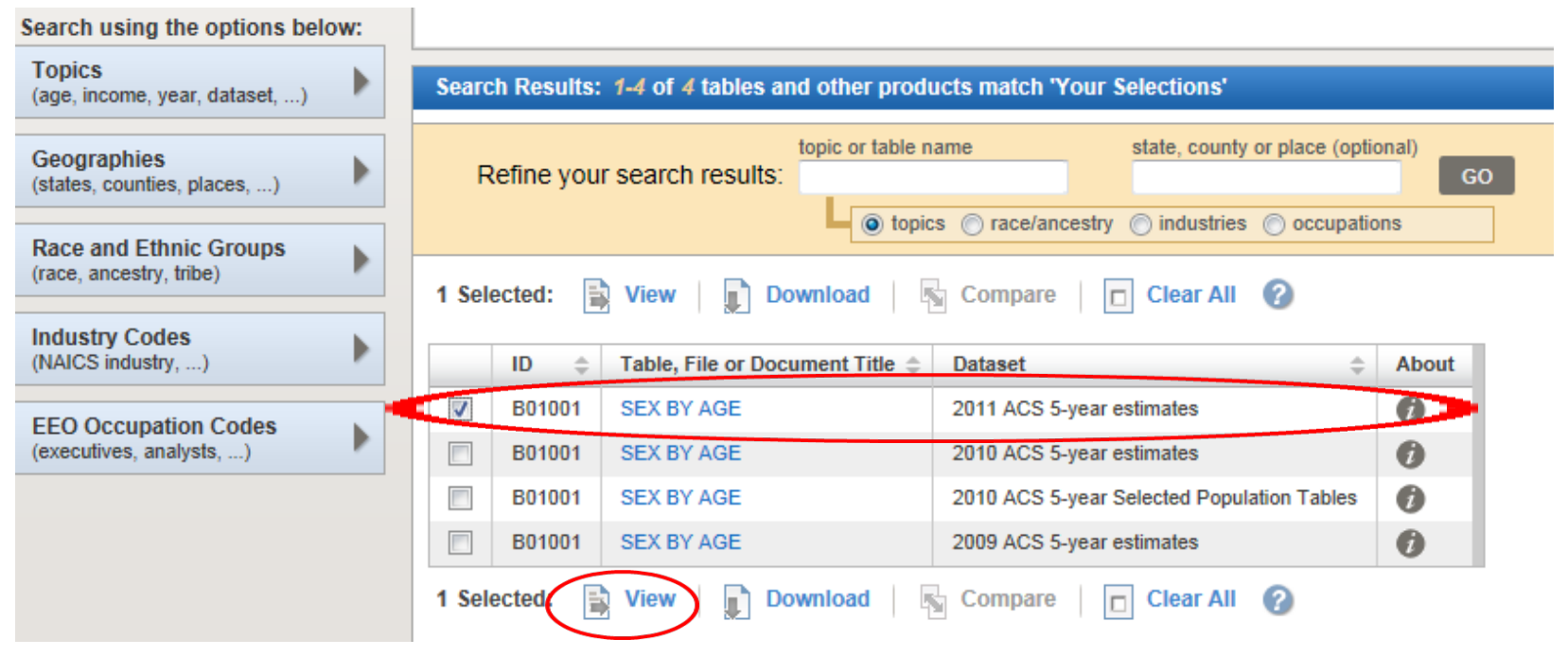

The following table will be displayed:

\begin{tabular}{|c|c|c|}
\hline & \multicolumn{2}{|c|}{ Holmes County, Florida } \\
\hline & Estimate & Margin of Error \\
\hline Total: & 20,003 & w.... \\
\hline Male: & 10,563 & $+/-154$ \\
\hline Under 5 years & 552 & $+/ 633$ \\
\hline 5 to 9 years & 761 & $+/-160$ \\
\hline 10 to 14 years & 491 & $+/=162$ \\
\hline 15 to 17 years & 421 & $+1-19$ \\
\hline 18 and 19 years & 240 & $+/-16$ \\
\hline 20 years & 64 & $+1-66$ \\
\hline 21 years & 221 & $+1-89$ \\
\hline 22 to 24 years & 465 & $+/-116$ \\
\hline 25 to 29 years & 739 & $+/-67$ \\
\hline 30 to 34 years & 648 & $+1-59$ \\
\hline 35 to 39 years & 718 & $+/-148$ \\
\hline 40 to 44 years & 813 & $+/-171$ \\
\hline 45 to 49 years & 768 & $* /-79$ \\
\hline 50 to 54 years & 742 & $+1-50$ \\
\hline 55 to 59 years & 596 & $* /-131$ \\
\hline 60 and 61 years & 268 & $+1-94$ \\
\hline 62 to 64 years & 493 & $* /-145$ \\
\hline 65 and 66 years & 168 & $+/-64$ \\
\hline 67 to 69 years & 425 & $+/-114$ \\
\hline 70 to 74 years & 368 & $+1-95$ \\
\hline 75 to 79 years & 241 & $+/-63$ \\
\hline 80 to 84 years & 229 & $+1-86$ \\
\hline 8s years and over & 132 & $+/-76$ \\
\hline Female: & 9,440 & $+/-154$ \\
\hline Under $\$$ years & $\$ 24$ & $+/-46$ \\
\hline 5 to 9 years & 440 & $+/ 122$ \\
\hline 10 to 14 years & 676 & $+/-122$ \\
\hline 15 to 17 years & 337 & $+/-104$ \\
\hline 18 and 19 years & 233 & $+1-65$ \\
\hline 20 years & 100 & +1.74 \\
\hline 21 years & 89 & $+1-65$ \\
\hline 22 to 24 years & 348 & $+/-91$ \\
\hline 25 to 29 years & 604 & $+/-115$ \\
\hline 30 to 34 years & 488 & $+1-63$ \\
\hline 35 to 39 years & 468 & $+/-150$ \\
\hline 40 to 44 years & 661 & $+/-149$ \\
\hline 45 to 49 years & 625 & $+/-12$ \\
\hline 50 to 54 years & 674 & $+/-19$ \\
\hline 55 to 59 years & 565 & $+/-144$ \\
\hline 60 and 61 years & 332 & $+/-118$ \\
\hline 62 to 64 years & 445 & $+/-119$ \\
\hline 65 and 66 years & 295 & $+/-76$ \\
\hline 67 to 69 years & 385 & $+/-83$ \\
\hline 70 to 74 years & 383 & $+/-92$ \\
\hline 75 to 79 years & 333 & $+/-97$ \\
\hline 80 to 84 years & 185 & $+1-69$ \\
\hline 85 years and over & 250 & $+/-92$ \\
\hline
\end{tabular}


Step 9 - Using the information from the above table (Sex and Age), add the male and female population together in each of the following age categories: <18 years, 18-64 years, and $65+$ years.

Step 10 - Return to previous page and click on "clear all selections."

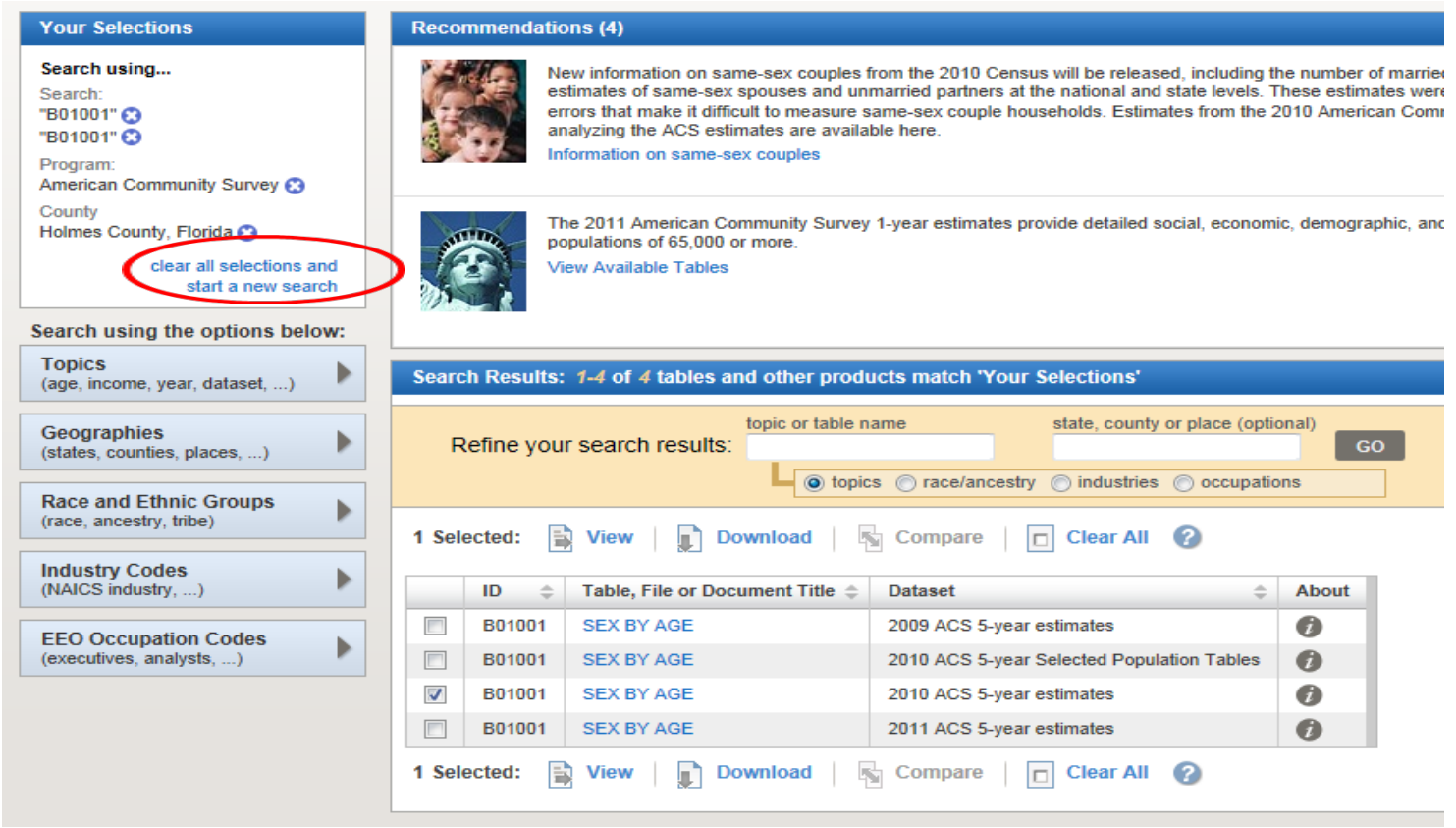

Step 11 - Type table number B17001 (Poverty Status by Sex and Age). Type in geography and click "go." In this example Holmes County is the selected geography.

Search - Use the options on the left (topics, geographies, ...) to narrow your search results

\begin{tabular}{|l|}
\hline Your Selections \\
\hline Your Selections' is empty \\
\hline Search using the options below: \\
\hline $\begin{array}{l}\text { Topics } \\
\text { (age, income, year, dataset, ...) }\end{array}$ \\
\hline $\begin{array}{l}\text { Geographies } \\
\text { (states, counties, places, ...) }\end{array}$ \\
\hline $\begin{array}{l}\text { Race and Ethnic Groups } \\
\text { (race, ancestry, tribe) }\end{array}$ \\
\hline \begin{tabular}{|l|}
\hline Industry Codes \\
(NAlCS industry, ...)
\end{tabular} \\
\hline $\begin{array}{l}\text { EEO Occupation Codes } \\
\text { (executives, analysts, ...) }\end{array}$ \\
\hline
\end{tabular}

To search for tables and other files in American FactFinder:

1 Enter search terms and an optional geography and click GO

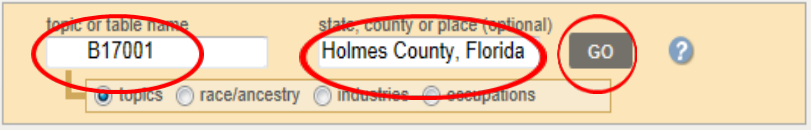

- or--

Select from Topics, Race and Ethnic Groups, Industry Codes, EEO Occupation Codes.

- these are added to 'Your Selections'

- the Search Results are updated

2 Next, select Geographies (states, counties, cities, towns, etc.)

- these are added to 'Your Selections'

- the Search Results are updated

3 Select one or more Search Results and click View 
Step 12 - Check table number B17001 for desired data set. Click "view." In this example the 2011 5-year estimates are used for Holmes County.

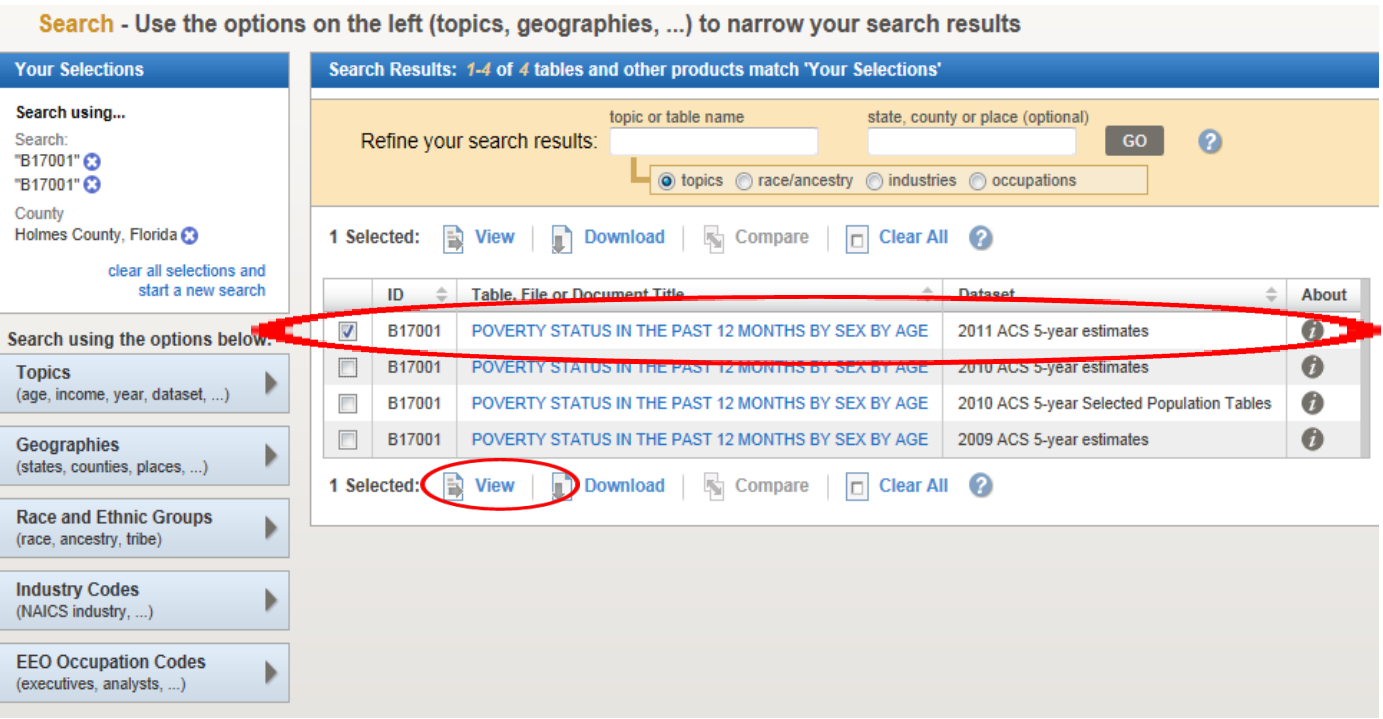

The following table will be displayed:

\begin{tabular}{|c|c|c|}
\hline & Holmea C & County, Florida \\
\hline & Eatimate & Margin of Error \\
\hline Total: & 18,192 & $+1-361$ \\
\hline Income in the past 12 months below poverty level: & 3,998 & $+1-628$ \\
\hline Male: & 1,901 & $+/-376$ \\
\hline Under 5 years & 231 & $+1-87$ \\
\hline 5 years & 75 & +-91 \\
\hline 6 to 11 years & 71 & $+1-58$ \\
\hline 12 to 14 years & 83 & $+1-79$ \\
\hline 15 years & 42 & $+1-42$ \\
\hline 16 and 17 years & 111 & $+1-69$ \\
\hline 18 to 24 years & 137 & $+1-88$ \\
\hline 25 to 34 years & 211 & $+;-123$ \\
\hline 35 to 44 years & 205 & $+/-119$ \\
\hline 45 to 54 years & 318 & $+F-136$ \\
\hline 55 to 64 years & 245 & $+l-112$ \\
\hline 65 to 74 years & 111 & $+1-90$ \\
\hline 75 years and over & 61 & $+1-39$ \\
\hline Female: & 2,097 & $+F-359$ \\
\hline Under 5 years & 160 & +-113 \\
\hline 5 years & o & $+[-104$ \\
\hline 6 to 11 years & 177 & $+1-96$ \\
\hline 12 to 14 years & 42 & $+1-45$ \\
\hline 15 years & 0 & $+>-104$ \\
\hline 16 and 17 years & 86 & $+1-67$ \\
\hline 18 to 24 years & 283 & ++129 \\
\hline 25 to 34 years & 201 & $+[-113$ \\
\hline 35 to 44 years & 411 & ++137 \\
\hline 45 to 54 years & 164 & $+1-73$ \\
\hline 55 to 64 years & 335 & $+F-129$ \\
\hline 65 to 74 years & 137 & $+1-80$ \\
\hline 75 years and over & 101 & $+1-49$ \\
\hline Income in the past 12 months at or above poverty level: & 14,194 & $+1-701$ \\
\hline Male: & 6,975 & $+=-419$ \\
\hline Under 5 years & 321 & +-95 \\
\hline 5 years & 67 & +-60 \\
\hline 6 to 11 years & 758 & +-141 \\
\hline 12 to 14 years & 179 & $+1-95$ \\
\hline 15 years & 66 & $+1-53$ \\
\hline 16 and 17 years & 173 & $+1-71$ \\
\hline 18 to 24 years & 559 & $+1-94$ \\
\hline 25 to 34 years & 697 & ++-144 \\
\hline 35 to 44 years & 845 & $+/-133$ \\
\hline 45 to 54 years & 989 & $+\mid-138$ \\
\hline 55 to 64 years & 1,004 & $+;-124$ \\
\hline 65 to 74 years & 824 & $+1-99$ \\
\hline 75 years and over & 493 & $+1-59$ \\
\hline Female: & 7.219 & $+1-377$ \\
\hline Under 5 years & 364 & $+f-115$ \\
\hline 5 years & 36 & $+\mid-41$ \\
\hline 6 to 11 years & 554 & $+f-138$ \\
\hline 12 to 14 years & 285 & $+F-119$ \\
\hline 15 years & 131 & $\begin{array}{r}-1-63 \\
+1-63\end{array}$ \\
\hline 16 and 17 years & 120 & $+\mid-51$ \\
\hline 18 to 24 years & 472 & $+s-100$ \\
\hline 25 to 34 years & 875 & $+F-126$ \\
\hline 35 to 44 years & 703 & $+/-155$ \\
\hline 45 to 54 years & 1,117 & $+1-86$ \\
\hline 55 to 64 years & 996 & $+f-152$ \\
\hline 65 to 74 years & 919 & $+1-83$ \\
\hline 75 years and over & 645 & $+1-55$ \\
\hline
\end{tabular}


Step 13 - Using the information from the previous table (Poverty Status in the Past 12 Months), add the male and female population together in each of the following categories: <18 years, 18-64 years, and 65+ years to prepare estimates of total population by age and poverty level.

Step 14 - Insert the results of Step 9 (Total Population by Age) and Step 13 (Population Below Poverty Level by Age) that correspond to the cells highlighted in yellow on the spreadsheet tool. Select the spreadsheet tab that corresponds with your county's PUMA designation. Holmes County is used in the example below.

The twelve counties in Florida with a 2011 population of approximately 20,000 or less are grouped into one of four PUMAs as shown below:

- PUMA 00400 - Holmes

- PUMA 00600 - Calhoun, Franklin, Gulf, Jefferson, Liberty, Madison

- PUMA 00800 - Dixie, Gilchrist, Hamilton, Lafayette

- PUMA 00900 - Union

Table 3-5

Required County Population Data Input for PUMA Areas

\begin{tabular}{|l|r|r|}
\hline $\begin{array}{c}\text { County } \\
\text { Population By } \\
\text { Age }\end{array}$ & $\begin{array}{c}\text { Total Pop by } \\
\text { Age }\end{array}$ & $\begin{array}{c}\text { Population } \\
\text { Below Poverty } \\
\text { Level by Age }\end{array}$ \\
\hline$<18$ & $\mathbf{4 , 2 0 2}$ & $\mathbf{1 , 0 7 8}$ \\
$18-64$ & $\mathbf{1 2 , 4 0 7}$ & $\mathbf{2 , 5 1 0}$ \\
\hline Total Non Elderly & 16,609 & 3,588 \\
\hline $65+$ & $\mathbf{3 , 3 9 4}$ & $\mathbf{4 1 0}$ \\
\hline Total Elderly & 3,394 & 410 \\
\hline Total & 20,003 & 3,998 \\
\hline
\end{tabular}

No user input is necessary for disability data for the counties shown above. The PUMA disability data have been pre-coded in the spreadsheet tool and will be applied to the ACS population by age and poverty level estimate inputs.

Step 14 completes all user required input for the Florida counties with populations of generally 20,000 or less. 


\section{Paratransit Demand Estimation Spreadsheet Calculations}

The user input described above is linked to other sections of the spreadsheet tool used to estimate demand. This section explains the methodologies used to calculate current estimates of the general TD population, the critical need TD population, and the demand for TD trips. This information is then linked to spreadsheet tabs that create projections of the general TD population and future demand for TD trips. Examples of completed spreadsheets are also presented.

As previously described, the recommended TD demand methodology will no longer use the 1993 process terminology to describe trips types (e.g., program trip or general trip) and trip categories. The new approach uses general TD populations, based upon estimates of all disabled, elderly and low-income persons, and children who are "high-risk" or "at-risk."

These population groups are further refined to identify the critical need TD populations, or those who due to severe physical limitations or low incomes are dependent upon others for their mobility needs.

After the critical need TD population is defined, daily trip rates are applied to calculate daily and annual travel demand. This methodology uses trip rates for persons who live in households without any vehicles available from the 2009 National Household Travel Survey (NHTS).

In Table 3-6, the user-generated population totals (age, income and disability) are displayed in blue. Because some individuals may fall into one or more of these demographic or socio-economic categories, it is necessary to eliminate the "double counts". The spreadsheet will automatically calculate the overlapping populations as displayed in the green spreadsheet and graphic. In this example, Indian River County has a non-duplicated general TD population of 61,033 individuals, or 44.7 percent of its total county population. 


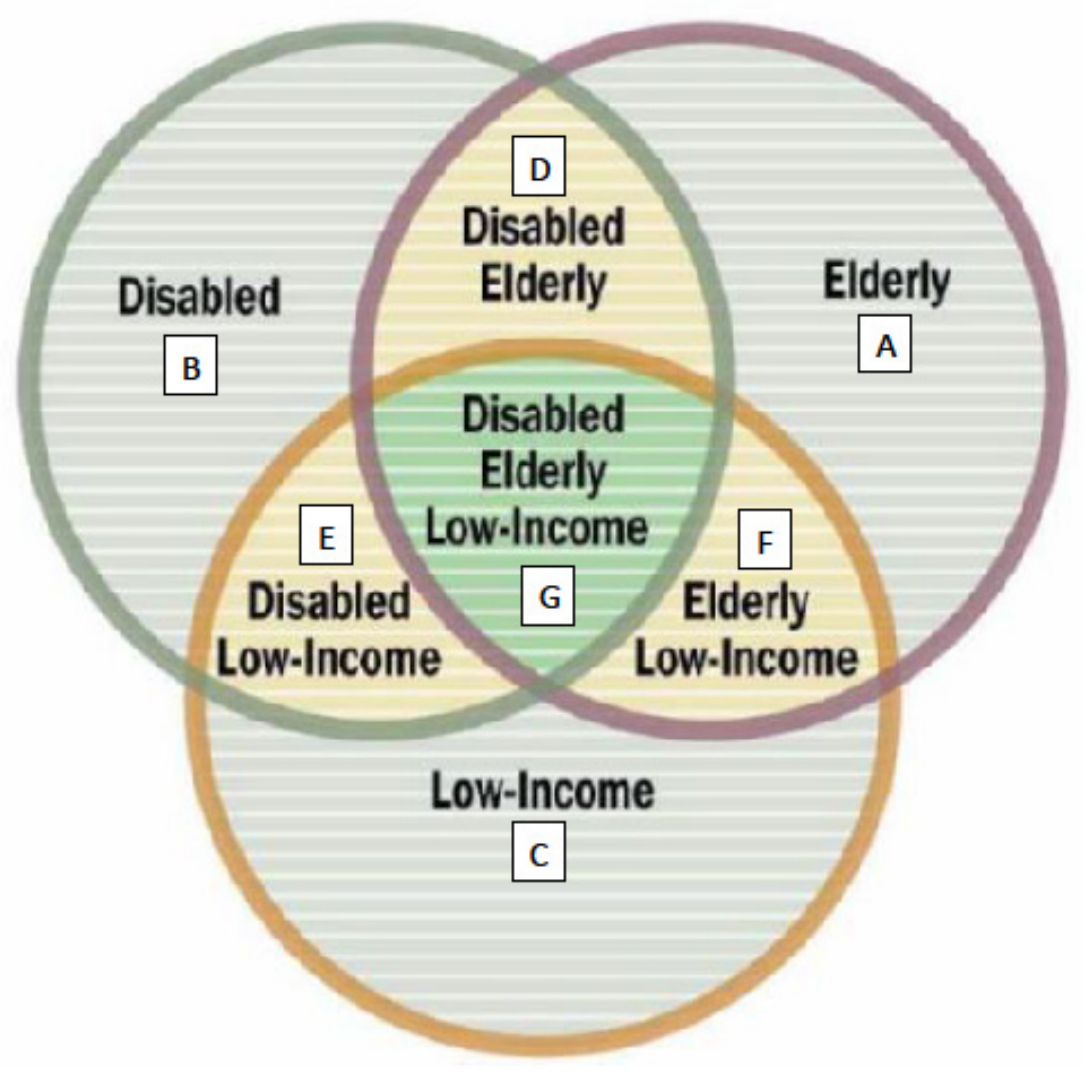

Figure 3-2

General Transportation Disadvantaged Population Groups 
Table 3-6

Calculation of General Transportation Disadvantaged Population

\begin{tabular}{|c|c|c|c|c|c|c|c|c|}
\hline \multirow[b]{2}{*}{ County Pop. By Age } & \multirow[b]{2}{*}{$\begin{array}{c}\text { Total Pop } \\
\text { by Age }\end{array}$} & \multicolumn{3}{|c|}{ Indian River County } & \multicolumn{2}{|c|}{ Census Data from } & 2011 & \multirow[b]{2}{*}{$\begin{array}{c}\text { \% Total Pop } \\
\text { with a Disability } \\
\text { and Below } \\
\text { Poverty Level } \\
\text { by Age }\end{array}$} \\
\hline & & $\begin{array}{l}\text { \% of Total } \\
\text { Pop } \\
(136,400)\end{array}$ & $\begin{array}{l}\text { Population } \\
\text { Below Poverty } \\
\text { Level by Age }\end{array}$ & $\begin{array}{l}\text { \% of Total } \\
\text { Pop Below } \\
\text { Poverty } \\
\text { Level by } \\
\text { Age }\end{array}$ & $\begin{array}{c}\text { Total } \\
\text { Population with } \\
\text { a Disability by } \\
\text { Age }\end{array}$ & $\begin{array}{c}\text { \% of Total Pop } \\
\text { with a Disability } \\
\text { by Age }\end{array}$ & $\begin{array}{l}\text { Total Pop with } \\
\text { Disability and } \\
\text { Below Poverty } \\
\text { Level by Age }\end{array}$ & \\
\hline$<5$ Vears of Age & 6,317 & $4.6 \%$ & 1,703 & $1.2 \%$ & 0 & $0.0 \%$ & 0 & $0.00 \%$ \\
\hline $5-17$ & 19,110 & $14.0 \%$ & 4,652 & $3.4 \%$ & 901 & $0.7 \%$ & 304 & $0.22 \%$ \\
\hline $18-34$ & 21,258 & $15.6 \%$ & 4,208 & $3.1 \%$ & 1,372 & $1.0 \%$ & 357 & $0.26 \%$ \\
\hline $35-64$ & 52,195 & $38.3 \%$ & 6,845 & $5.0 \%$ & 6,308 & $4.6 \%$ & 1,815 & $1.33 \%$ \\
\hline Total Non Elderly & 98,880 & $72.5 \%$ & 17,408 & $12.8 \%$ & 8,581 & $6.3 \%$ & 2,476 & $1.82 \%$ \\
\hline $65-74$ & 18,050 & $13.2 \%$ & 1,368 & $1.0 \%$ & 2,789 & $2.0 \%$ & 462 & $0.34 \%$ \\
\hline $75+$ & 19,470 & $14.3 \%$ & 1,454 & $1.1 \%$ & 8,744 & $6.4 \%$ & 887 & $0.65 \%$ \\
\hline Total Elderly & 37,520 & $27.5 \%$ & 2,822 & $2.1 \%$ & 11,533 & $8.5 \%$ & 1,349 & $0.99 \%$ \\
\hline Total & 136,400 & $100 \%$ & 20,230 & $14.8 \%$ & 20,114 & $14.7 \%$ & 3,825 & $2.80 \%$ \\
\hline \multicolumn{9}{|c|}{ Double Counts Galculations } \\
\hline \multicolumn{5}{|c|}{ E - Estimate non-elderly/disabled/ low income } & \multicolumn{3}{|c|}{ From Base Data (I11) } & 2,476 \\
\hline \multicolumn{5}{|c|}{ B - Estimate non-elderly/ disabled/not low income } & \multicolumn{3}{|c|}{ Subtract $\mathrm{H} 8$ from $\mathrm{FB}$} & 6,105 \\
\hline \multicolumn{5}{|c|}{$\mathrm{G}$ - Estimate elderly/disabled/low income } & \multicolumn{3}{|c|}{ From Base Data (I14) } & 1,349 \\
\hline \multicolumn{5}{|c|}{ D- Estimate elderly/ disabled/not low income } & \multicolumn{3}{|c|}{ Subtract I11 from G11 } & 10,184 \\
\hline \multicolumn{5}{|c|}{ F - Estimate elderly/non-disabled/low income } & \multicolumn{3}{|c|}{ Subtract I11 from E11 } & 1,473 \\
\hline \multicolumn{5}{|c|}{ A - Estimate elderly/non-disabled/not low income } & \multicolumn{3}{|c|}{ Subtract sum of $\mathrm{J} 17, \mathrm{~J} 18$ and $\mathrm{J} 19$ from $\mathrm{C} 11$} & 24,514 \\
\hline \multicolumn{5}{|c|}{ C- Estimate low income/not elderly/not disabled } & \multicolumn{3}{|l|}{ Subtract I8 from E8 } & 14,932 \\
\hline \multicolumn{5}{|l|}{ Total - Non-Duplicated } & & & & 61,033 \\
\hline
\end{tabular}

\begin{tabular}{|c|c|c|}
\hline \begin{tabular}{c} 
General TD Population \\
Non-Duplicated General TD \\
\cline { 2 - 3 } \begin{tabular}{c} 
Population Estimate \\
\cline { 3 - 3 }
\end{tabular}
\end{tabular} & $\mathbf{6 1 , 0 3 3}$ & \% of Total \\
\hline
\end{tabular}


Ideally, comparisons of disability estimates should be made using the same survey, geographic parameters, and disability definitions. However, because the severity of an individual's disability is not clearly captured by the six ACS questions, particularly as it relates to the need for specialized transportation, another source will be used for the next step in the demand methodology.

The U.S. Census Bureau's 2010 Survey of Income and Program Participation (SIPP) is a continuous series of national surveys conducted over the course of a $2 \frac{1}{2} 2$ - to 4 -year period with a sample size ranging from approximately 14,000 to 36,700 households. The SIPP collects demographic and socio-economic data used to measure the effectiveness and future costs associated with government programs.

The SIPP, through its supplemental questionnaires on adult and child functional limitations, asks questions about the ability of respondents to perform functional and participatory activities. When a respondent indicates having difficulty performing an activity, a follow-up question is used to determine the severity of the limitation. The responses to these and other questions are used to develop three overall measures of disability: any disability, severe disability, and needs assistance. ${ }^{14}$

In the SIPP, a person with a severe disability is defined as:

- Deaf, blind, or was unable to see, hear, or have speech understood (aged 6 and older

- Unable to perform one or more of the functional activities (aged 15 and older

- Used a wheelchair, cane, crutches, or walker (aged 6 and older)

- Needed assistance of another person to perform one or more of the Assistance with Activities of Daily Living

- Needed assistance of another person to perform one or more of the Instrumental Activities of Daily Living

- Had difficulty finding a job or remaining employed (aged 16 to 72)

- Had Alzheimer's disease, dementia, or senility (aged 15 and older)

- Had a developmental delay (under 6 years)

- Had an intellectual disability of developmental disability, such as autism or cerebral palsy (aged 6 and older)

- Had some other developmental condition for which received therapy or diagnostic services (aged 6 to 14 )

- Had one or more selected symptoms that interfere with everyday activities: was frequently depressed or anxious, had trouble getting along with others, had trouble concentrating, or had trouble coping with stress (aged 15 and older). 
Figure 3-3 displays the disability prevalence and the need for assistance by age as reported in the 2010 SIPP release.

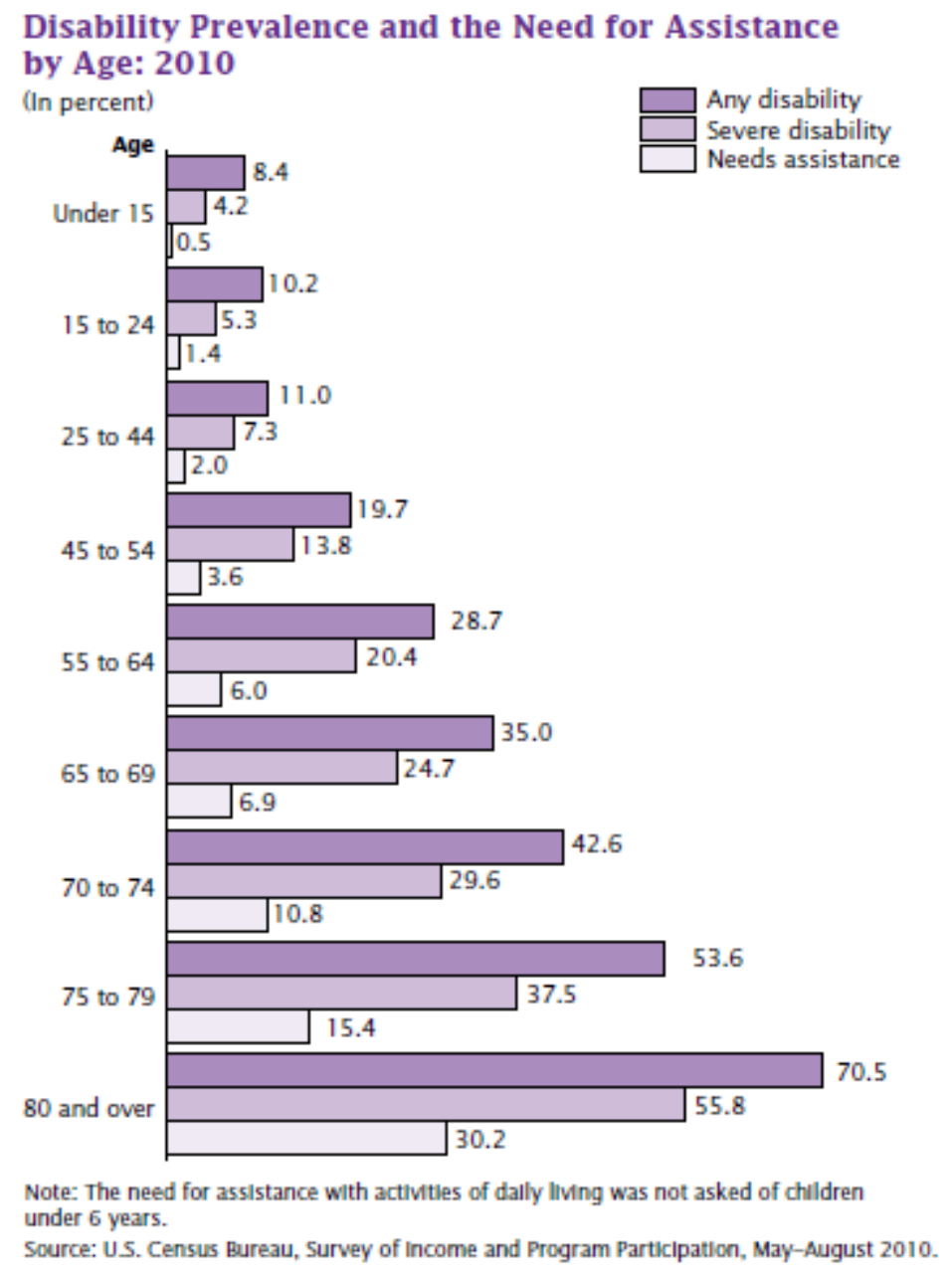

Figure 3-3

Disability Prevalence and the Need for Assistance by Age

Because the SIPP age thresholds do not directly correspond to the ACS data used to calculate the general TD population, the severe disability rates (or average rates) that most closely correspond to the ACS age brackets are used in the demand methodology to estimate the prevalence of a severe disability by Florida county. In the demand methodology, these are the individuals identified as having a "critical need" for transportation based on their disability status.

A sample from the critical needs tab of the spreadsheet workbook is shown on Table 3-7. In this example, Indian River County has an estimated 5,824 residents with a need for transportation due to a severe disability. 
Table 3-7

Calculation of Critical Need Transportation Disadvantaged Population with Severe Disabilities

Indian River County

\begin{tabular}{|c|c|c|c|c|}
\hline County Pop. By Age & $\begin{array}{c}\text { Total Population with a } \\
\text { Disability by Age }\end{array}$ & $\begin{array}{c}\text { \% with a } \\
\text { Severe } \\
\text { Disability } \\
\text { by Age }\end{array}$ & $\begin{array}{l}\text { Total Population } \\
\text { with a Severe } \\
\text { Disability by Age }\end{array}$ & $\begin{array}{c}\% \text { of Total Pop } \\
\text { with Severe } \\
\text { Disability by Age }\end{array}$ \\
\hline$<5$ Years of Age & 0 & $4.20 \%$ & - & - \\
\hline $5-17$ & 901 & $4.20 \%$ & 38 & $0.20 \%$ \\
\hline $18-34$ & 1,372 & $6.30 \%$ & 86 & $0.41 \%$ \\
\hline $35-64$ & 6,308 & $13.84 \%$ & 873 & $1.67 \%$ \\
\hline Total Non Elderly & 8,581 & & 997 & $1.01 \%$ \\
\hline $65-74$ & 2,789 & $27.12 \%$ & 756 & $4.19 \%$ \\
\hline $75+$ & 8,744 & $46.55 \%$ & 4,070 & $20.91 \%$ \\
\hline Total Elderly & 11,533 & & 4,827 & $12.86 \%$ \\
\hline Total & 20,114 & & 5,824 & $4.27 \%$ \\
\hline
\end{tabular}

Census Data from:

2011

\begin{tabular}{|r|r|}
\hline $\begin{array}{c}\text { \% of Severe } \\
\text { Disability Below } \\
\text { Poverty Level }\end{array}$ & $\begin{array}{c}\text { Total Severe } \\
\text { Disability Below } \\
\text { Poverty Level }\end{array}$ \\
\hline & \\
\hline & \\
\hline & \\
\hline & \\
\hline $28.60 \%$ & \\
\hline & \\
\hline & \\
\hline $11.70 \%$ & \\
\hline & \\
\hline
\end{tabular}


Data from the most recent (2009) National Household Travel Survey (NHTS) is used for the next step of the demand methodology. Sponsored by the Federal Highway Administration, the NHTS is conducted approximately every eight years to collect in-depth information at the individual and household levels about travel patterns including, but not limited to, trip purpose, mode, vehicle availability and travel time. List-assisted random digit dialing computer-assisted telephone interviews were utilized to collect a sample of 150,147 households for the most recent NHTS.

For purposes of forecasting paratransit demand, the trip rates for households with zero vehicles available are used. This is based on the assumption that the elderly, low income, and disabled who make up Florida's TD population are more likely to reside in households with zero vehicles and/or their travel demand would be similar to households with zero vehicles available versus households with vehicles and unconstrained use.

Based on the 2009 NHTS, the per capita trip rate for Florida households with zero vehicles available averaged 2.4 trips per day. Of the 2.4 trips per day, 0.389 were made on transit, 0.063 on school buses, and 0.049 on special services for people with disabilities. ${ }^{15}$ These three modes are subtracted from the 2.4 trips per day to arrive at the daily trip rate for the low income, non-disabled without access to automobiles or public transit. These trips were made using a variety of modes including: privately operated (but not household owned) vehicles as a passenger or driver, bicycle, walking, taxi or "other."

The daily trip rate for those individuals with severe disabilities would fall within the specialized transit rate of 0.049 trips per day.

In the spreadsheet tool, these rates are applied to the various critical need TD population groups as follows:

- Based on rates from the 2009 NHTS for the United States, of the 16,405 low-income, non-disabled residents of Indian River County, approximately 27.2 percent $(4,249)$ live in zero vehicle households.

- Based on user provided input, 15 percent of the low income, non-disabled population without auto access also does not have access to public transit (637 individuals). This group is reliant on other means of transportation for 1,271 daily trips.

- The TD population with critical needs due to severe disabilities (i.e., critical need TD population) of 5,824 could be expected to make 285 daily paratransit trips.

- Combined, the estimated total daily demand for critical need TD trips in Indian River County is 1,556 trips. 
Table 3-8

Calculation of Critical Need Transportation Disadvantaged Population and Trips

\begin{tabular}{|r|r|r|r|}
\hline \multicolumn{3}{|c|}{ Critical Need - Severely Disabled TD Population } \\
\hline & Not Low Income & Low Income & \multicolumn{1}{|c|}{ Totals } \\
\hline Non-Elderly & 712 & 285 & 997 \\
\hline Elderly & 4,262 & 565 & 4,827 \\
\hline \multicolumn{5}{|c|}{$\mathbf{4 , 9 7 4}$} & $\mathbf{8 5 0}$ & $\mathbf{5 , 8 2 4}$ \\
\hline
\end{tabular}

\begin{tabular}{|cc|}
\hline \multicolumn{2}{|c|}{ TRIP RATES USED } \\
\hline Low Income Non Disabled Trip Rate \\
\hline $\begin{array}{cc}\text { Total } \\
\text { Less }\end{array}$ & 2.400 \\
\hline Transit & \\
School Bus & $\mathbf{0 . 3 8 9}$ \\
Special Transit & $\mathbf{0 . 0 6 3}$ \\
${\mathbf{0 . 0 4 9}} \\
{\hline} &{\mathbf{1 . 8 9 9}} \\
{\hline \text { Severely Disabled Trip Rate }} &{ } \\
{\hline \text { Special Transit }} &{\mathbf{0 . 0 4 9}} \\
{\hline}$
\end{tabular}

\begin{tabular}{|c|c|c|c|c|}
\hline$\frac{\text { Assumes }}{27.2 \%}$ & \multicolumn{2}{|c|}{$\begin{array}{c}16,405 \\
x \times \% \text { without auto access }\end{array}$} & \multicolumn{2}{|c|}{$\begin{array}{c}\text { CALCULATION OF DAILY TRIPS } \\
\text { FOR THE } \\
\text { CRITICAL NEED TD POPULATION }\end{array}$} \\
\hline \multirow[t]{5}{*}{$15.0 \%$} & xx \% without trans & $\begin{array}{l}4,462 \\
\text { iccess }\end{array}$ & \multirow{2}{*}{\multicolumn{2}{|c|}{ Calculation of Daily Trips }} \\
\hline & & 669 & & \\
\hline & \multicolumn{2}{|c|}{ Total Actual Critical TD Population } & $\begin{array}{l}\text { Daily Trip Rates } \\
\text { Per Person } \\
\end{array}$ & $\begin{array}{c}\text { Total } \\
\text { Daily Trips }\end{array}$ \\
\hline & $\begin{array}{l}\text { Severely Disabled } \\
\text { Low Income ND }\end{array}$ & $\begin{array}{c}5,824 \\
669\end{array}$ & $\begin{array}{l}0.049 \\
1.899\end{array}$ & $\begin{array}{r}285 \\
1,271\end{array}$ \\
\hline & Totals & 6,493 & & 1,556 \\
\hline
\end{tabular}


Based on the 2011 ACS, projections can be developed for specific populations at future points in time. Table 3-8 displays the forecasts of the general and critical need TD population for Indian River County. The projections are based on the estimates prepared in Step 13 using the Bureau of Economic and Business Research data.

By using the population projections and applying the trip rate estimates that were developed for each county, the spreadsheet tool will automatically calculate the annual trip demand for critical need paratransit services in the future. The annual trips are calculated by multiplying the estimated daily trips by the number of days per year special services operate derived from the user direct input table.

As shown in Table 3-9, Indian River County's annual trip demand is estimated to increase from 545,921 in the 2011 base year to 647,302 in 2021. 
Table 3-9

Forecast of General and Critical Need Transportation Disadvantaged Population and Trips

\begin{tabular}{|c|c|c|c|c|c|c|c|c|c|c|c|}
\hline General TD Population Forecast & 2011 & 2012 & 2013 & 2014 & 2015 & 2016 & 2017 & 2018 & 2019 & 2020 & 2021 \\
\hline \multicolumn{12}{|l|}{ Overlapping Circle Component } \\
\hline E - Estimate non-elderly/disabled/low income & 2,476 & 2,518 & 2,561 & 2,604 & 2,649 & 2,694 & 2,740 & 2,786 & 2,833 & 2,882 & 2,931 \\
\hline B - Estimate non-elderly/disabled/not low income & 6,105 & 6,209 & 6,314 & 6,422 & 6,531 & 6,642 & 6,755 & 6,870 & 6,986 & 7,105 & 7,226 \\
\hline G - Estimate elderly/disabled/low income & 1,349 & 1,372 & 1,395 & 1,419 & 1,443 & 1,468 & 1,493 & 1,518 & 1,544 & 1,570 & 1,597 \\
\hline D- Estimate elderly/disabled/not low income & 10,184 & 10,357 & 10,533 & 10,712 & 10,894 & 11,080 & 11,268 & 11,459 & 11,654 & 11,852 & 12,054 \\
\hline F - Estimate elderly/non-disabled/low income & 1,473 & 1,498 & 1,524 & 1,549 & 1,576 & 1,603 & 1,630 & 1,657 & 1,686 & 1,714 & 1,743 \\
\hline A - Estimate elderly/non-disabled/not low income & 24,514 & 24,931 & 25,355 & 25,786 & 26,224 & 26,670 & 27,123 & 27,584 & 28,053 & 28,530 & 29,015 \\
\hline C - Estimate low income/not elderly/not disabled & 14,932 & 15,186 & 15,444 & 15,707 & 15,974 & 16,245 & 16,521 & 16,802 & 17,088 & 17,378 & 17,674 \\
\hline TOTAL GENERAL TD POPULATION & 61,033 & 62,071 & 63,126 & 64,199 & 65,290 & 66,400 & 67,529 & 68,677 & 69,845 & 71,032 & 72,239 \\
\hline TOTAL POPULATION & 136,400 & 138,719 & 141,077 & 143,475 & 145,914 & 148,395 & 150,918 & 153,483 & 156,092 & 158,746 & 161,445 \\
\hline & & & & & & & & & & & \\
\hline
\end{tabular}

\begin{tabular}{|c|c|c|c|c|c|c|c|c|c|c|c|}
\hline Critical Need TD Population Forecast & 2011 & 2012 & 2013 & 2014 & 2015 & 2016 & 2017 & 2018 & 2019 & 2020 & 2021 \\
\hline \multicolumn{12}{|l|}{ Total Critical TD Population } \\
\hline Disabled & 5,824 & 5,923 & 6,024 & 6,126 & 6,230 & 6,336 & 6,444 & 6,553 & 6,665 & 6,778 & 6,893 \\
\hline Low Income Not Disabled No Auto/Transit & 669 & 681 & 692 & 704 & 716 & 728 & 741 & 753 & 766 & 779 & 792 \\
\hline Total Critical Need TD Population & 6,493 & 6,604 & 6,716 & 6,830 & 6,946 & 7,064 & 7,184 & 7,307 & 7,431 & 7,557 & 7,686 \\
\hline \multicolumn{12}{|l|}{ Daily Trips - Critical Need TD Population } \\
\hline Severely Disabled & 285 & 290 & 295 & 300 & 305 & 310 & 316 & 321 & 327 & 332 & 338 \\
\hline Low Income - Not Disabled - No Access & 1,271 & 1,293 & 1,315 & 1,337 & 1,360 & 1,383 & 1,406 & 1,430 & 1,455 & 1,479 & 1,504 \\
\hline Total Daily Trips Critical Need TD Population & 1,556 & 1,583 & 1,609 & 1,637 & 1,664 & 1,694 & 1,724 & 1,754 & 1,785 & 1,817 & 1,845 \\
\hline Annual Trips & 568,094 & 577,695 & 587,458 & 597,386 & 607,482 & 618,235 & 629,177 & 640,314 & 651,647 & 663,181 & 673,593 \\
\hline & & & & & & & & & & & \\
\hline
\end{tabular}




\section{Chapter 4 Summary}

The paratransit demand methodology currently utilized by many CTCs and public transportation operators for the preparation of TDSPs and other demand estimation applications within the state of Florida was developed in 1993. The methodology was based on trip rates that were derived from a 1988 UMTA study that utilized trip rates from the San Francisco area.

While the methodology was appropriate at the time, the CTD has matured, and with the passage of the ADA in 1990, significant changes have occurred in terms of the mobility options that are available for persons with disabilities. For example, as a result of the passage of the ADA, many of the transportation disadvantaged trips can be accommodated by a community's fixed-route transit services. Based on these changes, the definitions and categories used in the existing methodology may no longer be appropriate or relevant for the examination of the TD population or their travel needs.

Additionally, the existing methodology was based on 1990 U.S. Census data. This outdated data source could not account for changes in the population occurring in the 20 years since the methodology's development. Much of the demographic and socio-economic data that is necessary for the preparation of TD population and demand forecasts are now collected by the U.S. Census Bureau on an annual basis. This richer data source captures changing population characteristics that influence transportation demand.

As a result of this research effort, a dynamic spreadsheet tool was developed to assist Florida transportation planners with TD demand forecasting. Unlike the existing tool, it does require some user input, but the inputs are straightforward and can be completed by almost anyone with basic computer skill sets. The tool does not require complex data or specialized software often required of more sophisticate models; resources that may not be available to all agencies.

Step by step instructions are provided for accessing the required inputs including: U.S. Census Bureau's American Community Survey ACS age, income, and disability data and county level population projections. Other data used in the model, such as those from the National Household Travel Survey and the U.S. Census Bureau's SIPP, have been pre-coded in the spreadsheet tool for ease of use.

The TD methodology described in this report can serve as a resource which is easily updated with current data, enables users to better analyze various sub-components of the TD market, and can be complemented with local knowledge and information for further customization.

This methodology has the ability to be adapted to provide estimates in other settings, including other states, communities and sub-regional areas. 


\section{Appendix A}

\section{List of Acronyms}




\title{
List of Acronyms
}

\author{
ACS - American Community Survey \\ ADA - Americans with Disabilities Act \\ BEBR - Bureau of Economic and Business Research \\ CTC - Community Transportation Coordinator \\ CTD - Commission for the Transportation Disadvantaged \\ CUTR - Center for Urban Transportation Research \\ FTA - Federal Transit Administration \\ LCB - Local Coordination Board \\ MOA - Memorandum of Agreement \\ NHTS - National Household Travel Survey \\ NCSR - National Center for Senior Transportation \\ PUMA - Public Use Microdata Area \\ SIPP - Survey of Income and Program Participation \\ TCRP - Transit Cooperative Research Project \\ TD - Transportation Disadvantaged \\ TDSP - Transportation Disadvantaged Service Plan \\ UMTA - Urban Mass Transportation Administration
}




\section{Appendix B}

University of Florida, Bureau of Economic and Business Research, Florida Population Studies, Bulletin 162 (Revised), March 2012 


\section{Medium Projections of Florida Population by County, 2011-2040 (Revised)}

\begin{tabular}{|c|c|c|c|c|c|c|c|}
\hline \multirow{2}{*}{$\begin{array}{l}\text { County } \\
\text { and State }\end{array}$} & \multirow{2}{*}{$\begin{array}{r}\text { Estimates } \\
\text { April 1, } 2011\end{array}$} & \multicolumn{6}{|c|}{ Projections, April 1} \\
\hline & & 2015 & 2020 & 2025 & 2030 & 2035 & 2040 \\
\hline Alachua & 247,337 & 255,549 & 268,303 & 280,647 & 292,517 & 303,870 & 314,831 \\
\hline Baker & 26,827 & 28,688 & 30,902 & 33,072 & 35,151 & 37,132 & 39,041 \\
\hline Bay & 169,278 & 174,854 & 185,481 & 195,625 & 205,072 & 213,796 & 222,010 \\
\hline Bradford & 28,662 & 28,033 & 28,857 & 29,646 & 30,408 & 31,141 & 31,854 \\
\hline Brevard & 545,184 & 561,155 & 591,530 & 620,462 & 647,346 & 672,116 & 695,385 \\
\hline Broward & $1,753,162$ & $1,775,264$ & $1,816,224$ & $1,853,626$ & $1,886,564$ & $1,915,231$ & $1,946,355$ \\
\hline Calhoun & 14,685 & 15,057 & 15,738 & 16,375 & 16,869 & 17,520 & 18,040 \\
\hline Charlotte & 160,463 & 164,784 & 173,129 & 181,028 & 188,302 & 194,940 & 201,123 \\
\hline Citrus & 140,856 & 146,620 & 157,201 & 167,399 & 177,017 & 186,018 & 194,591 \\
\hline Clay & 191,143 & 204,784 & 229,172 & 252,517 & 274,711 & 285,674 & 315,749 \\
\hline Collier & 323,785 & 341,859 & 375,585 & 408,254 & 439,367 & 468,770 & 497,011 \\
\hline Columbia & 67.528 & 70,518 & 75,193 & 79,686 & 83,808 & 87,844 & 91,580 \\
\hline DeSoto & 34,708 & 35,460 & 36,709 & 37,924 & 39,004 & 40,214 & 41,300 \\
\hline Dixie & 16,385 & 17,434 & 18,596 & 19,713 & 20,760 & 21,735 & 22,658 \\
\hline Duval & 864,601 & 887,202 & 928,135 & 967,649 & $1,003,844$ & $1,038,403$ & $1,071,594$ \\
\hline Escambia & 299,261 & 301,296 & 305,433 & 309,396 & 313,078 & 316,465 & 319,652 \\
\hline Flagler & 96,241 & 108,481 & 129,894 & 150,548 & 170,186 & 188,736 & 206,500 \\
\hline Franklin & 11,527 & 11,973 & 12,062 & 12,147 & 12,226 & 12,299 & 12,367 \\
\hline Gadsden & 48,200 & 49,009 & 50,142 & 51,241 & 52,285 & 53,304 & 54,278 \\
\hline Gilchrist & 16,983 & 17,657 & 18,950 & 20,194 & 21,363 & 22,455 & 23,491 \\
\hline Glades & 12,812 & 13,286 & 14,135 & 14,853 & 15,723 & 16,442 & 17.127 \\
\hline Gulf & 15,789 & 15,862 & 15,991 & 16,092 & 16,159 & 16,196 & 16,209 \\
\hline Hamilton & 14,744 & 15,151 & 15,627 & 16,088 & 16,531 & 16,955 & 17,364 \\
\hline Hardee & 27,653 & 27,871 & 28,205 & 28,528 & 28,836 & 29,129 & 29,411 \\
\hline Hendry & 38,908 & 38,488 & 39,615 & 40,665 & 41,620 & 42,484 & 43,279 \\
\hline Hernando & 173,078 & 184,246 & 204,398 & 223,632 & 241,913 & 259,178 & 275,710 \\
\hline Highlands & 98,712 & 101,482 & 106,770 & 111,796 & 116,453 & 120,731 & 124,740 \\
\hline Hillsborough & $1,238,951$ & $1,302,438$ & $1,420,360$ & $1,532,174$ & $1,639,438$ & $1,740,578$ & $1,836,831$ \\
\hline Holmes & 19,901 & 20,190 & 20,673 & 21,114 & 21,505 & 21,877 & 22,261 \\
\hline Indian River & 138,694 & 145,613 & 158,501 & 170,831 & 182,584 & 183,592 & 204,134 \\
\hline Jackson & 49,964 & 50,450 & 50,799 & 51,134 & 51,459 & 51,773 & 52,077 \\
\hline Jefferson & 14,666 & 14,859 & 15,557 & 16,122 & 16,641 & 17.113 & 17,552 \\
\hline Lafayette & 8,752 & 9,068 & 9,538 & 9,994 & 10,431 & 10,847 & 11,248 \\
\hline Lake & 298,265 & 321,175 & 361,789 & 400,755 & 437,813 & 472,831 & 506,376 \\
\hline
\end{tabular}

Source: University of Florida, Bureau of Economic and Business Research, Flonda Population Studles, Bulleth 162 (Revised). March 2012 


\section{Medium Projections of Florida Population by County, 2011-2040 (Revised)}

\begin{tabular}{|c|c|c|c|c|c|c|c|}
\hline \multirow{2}{*}{$\begin{array}{l}\text { County } \\
\text { and State }\end{array}$} & \multirow{2}{*}{$\begin{array}{r}\text { Estimates } \\
\text { April 1, } 2011\end{array}$} & \multicolumn{6}{|c|}{ Projections, April 1} \\
\hline & & 2015 & 2020 & 2025 & 2030 & 2035 & 2040 \\
\hline Lee & 625,310 & 674,992 & 763,232 & 847,963 & 928,484 & $1,004,503$ & $1,077,279$ \\
\hline Leon & 276,278 & 283,159 & 296,217 & 308,689 & 320,316 & 331,066 & 341,195 \\
\hline Levy & 40,767 & 42,482 & 45,727 & 48,846 & 51,775 & 54,504 & 57,093 \\
\hline Liberty & 8,370 & 9,286 & 9,890 & 10,479 & 11,050 & 11,599 & 12,133 \\
\hline Madison & 19,298 & 19,442 & 19,561 & 19,677 & 19,789 & 19,896 & 20,000 \\
\hline Manatee & 325,905 & 341,583 & 370,700 & 398,897 & 425,458 & 450,445 & 474,383 \\
\hline Marion & 331,745 & 351,780 & 388,261 & 422,952 & 455,832 & 487,088 & 516,926 \\
\hline Martin & 146,689 & 151,590 & 160,897 & 169,792 & 178,093 & 185,773 & 193,017 \\
\hline Miami-Dade & $2,516,515$ & $2,591,790$ & $2,717,631$ & $2,840,533$ & $2,959,348$ & $3,071,498$ & $3,179,748$ \\
\hline Monroe & 72,670 & 72,074 & 70,863 & 69,702 & 68,624 & 67,633 & 66,700 \\
\hline Nassau & 73,684 & 78,599 & 86,584 & 94,541 & 102,213 & 109,560 & 116,677 \\
\hline Okaloosa & 181,679 & 184,908 & 191,470 & 197,757 & 203,597 & 208,970 & 214,026 \\
\hline Okeechobee & 39,870 & 40,887 & 42,548 & 44,133 & 45,577 & 46,879 & 48,157 \\
\hline Orange & $1,157,342$ & $1,226,823$ & $1,355,676$ & $1,480,887$ & $1,597,847$ & $1,708,321$ & $1,814,093$ \\
\hline Osceola & 273,867 & 303,380 & 353,078 & 402,251 & 449,082 & 492,964 & 534,853 \\
\hline Palm Beach & $1,325,758$ & $1,372,682$ & $1,461,234$ & $1,546,129$ & $1,625,651$ & $1,699,536$ & $1,769,470$ \\
\hline Pasco & 466,533 & 498,004 & 554,376 & 608,275 & 659,528 & 707,952 & 754,334 \\
\hline Pinellas & 918,496 & 917,520 & 915,536 & 913,635 & 911,869 & 910,244 & 908,715 \\
\hline Polk & 604,792 & 640,023 & 688,930 & 757.017 & 812,835 & 866,399 & 918,136 \\
\hline Putnam & 74,052 & 74,635 & 75,835 & 76,886 & 77,720 & 78,561 & 79,422 \\
\hline Saint Johns & 192,852 & 213,864 & 247,665 & 281,416 & 314,514 & 346,573 & 377,014 \\
\hline Saint Lucie & 279,696 & 304,551 & 346,572 & 387,715 & 426,786 & 463,635 & 498,889 \\
\hline Santa Rosa & 154,901 & 164,569 & 181,695 & 198,196 & 213,697 & 228,341 & 242,362 \\
\hline Sarasota & 381,319 & 394,783 & 420,152 & 444,483 & 467,286 & 488,487 & 508,564 \\
\hline Seminole & 424,587 & 438,050 & 463,645 & 488,074 & 510,826 & 531,838 & 551,622 \\
\hline Sumter & 96,615 & 110,017 & 130,774 & 151,349 & 171,684 & 191,643 & 211,337 \\
\hline Suwannee & 43,215 & 45,012 & 47,990 & 50,844 & 53,516 & 55,997 & 58,344 \\
\hline Taylor & 22,500 & 23,089 & 23,652 & 24,194 & 24,708 & 25,192 & 25,654 \\
\hline Union & 15,473 & 15,996 & 16,644 & 17,275 & 17,872 & 18,445 & 18,999 \\
\hline Volusia & 495,400 & 505,979 & 526,375 & 545,552 & 563,083 & 578,957 & 593,632 \\
\hline Wakulla & 30,877 & 32,548 & 35,595 & 38,551 & 41,360 & 44,009 & 46,549 \\
\hline Walton & 55,450 & 59,438 & 68,729 & 73,743 & 80,346 & 86,584 & 92,559 \\
\hline Washington & 24,638 & 25,383 & 26,715 & 27,983 & 29,160 & 30,243 & 31,259 \\
\hline FLORIDA & $18,905,048$ & $19,664,972$ & $21,021,643$ & $22,329,543$ & $23,567,010$ & $24,730,724$ & $25,846,980$ \\
\hline
\end{tabular}

Source: University of Florida, Bureau of Economic and Business Research, Florida Population Studles, Bulleth 162 (Revised). March 2012 


\section{References}

${ }^{1}$ A Profile of Older Americans: 2011, U.S. Department of Health and Human Services, Administration on Aging.

${ }^{2}$ F. Ron Jones, Steven Mass and Patrick Griffith," Methodology Guidelines for Forecasting TD Transportation Demand at the County Level," University of South Florida Center for Urban Transportation Research, Tampa, Florida, 1993.

${ }^{3}$ Ibid.

${ }^{4}$ Ibid.

${ }^{5}$ Ibid.

${ }^{6}$ Ibid.

7 Sandra Rosenbloom, How to Predict and Control Ridership for Community Transportation Systems; A Ridership Manual, The Center for Transportation Research, University of Texas at Austin, 1982.

${ }^{8}$ Ibid.

${ }^{9}$ Ibid.

${ }^{10}$ David Koffman, David Lewis, David Chia, Jon Burkhardt and Mark Bradley, Improving ADA Complementary Paratransit Demand Estimation, TCRP Report 119, Transportation Research Board, 2007.

${ }^{11}$ Ibid.

12 Ibid.

13 Mark Bradley and David Koffman, Improving ADA Paratransit Demand Estimation: Regional Modeling, TCRP Report 158, Transportation Research Board, 2012.

${ }^{14}$ Americans with Disabilities: 2005 Household Economic Study, U.S Census Bureau, Matthew W. Brault.

152009 National Household Travel Survey, U.S. Department of Transportation, Federal Highway Administration, Office of Highway Policy Information. 